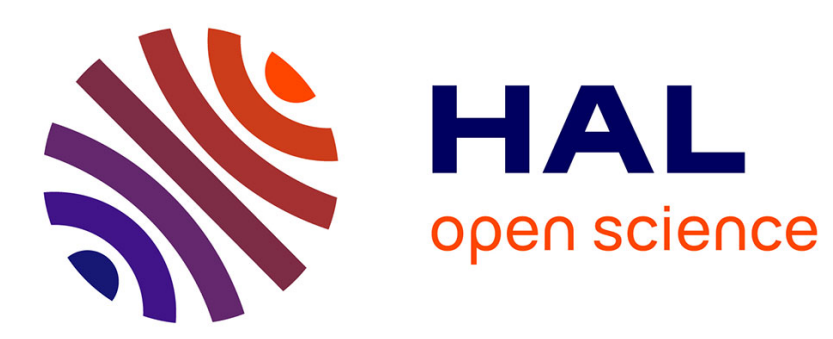

\title{
Biodistribution and targeting properties of iron oxide nanoparticles for treatments of cancer and iron anemia disease
}

Edouard Alphandéry

\section{- To cite this version:}

Edouard Alphandéry. Biodistribution and targeting properties of iron oxide nanoparticles for treatments of cancer and iron anemia disease. Nanotoxicology, 2019, 13 (5), pp.573-596. 10.1080/17435390.2019.1572809 . hal-02285042

\section{HAL Id: hal-02285042 \\ https: / hal.sorbonne-universite.fr/hal-02285042}

Submitted on 12 Sep 2019

HAL is a multi-disciplinary open access archive for the deposit and dissemination of scientific research documents, whether they are published or not. The documents may come from teaching and research institutions in France or abroad, or from public or private research centers.
L'archive ouverte pluridisciplinaire HAL, est destinée au dépôt et à la diffusion de documents scientifiques de niveau recherche, publiés ou non, émanant des établissements d'enseignement et de recherche français ou étrangers, des laboratoires publics ou privés. 


\title{
Biodistribution and targeting properties of iron oxide
}

\author{
Edouard Alphandéry ${ }^{+, *,++}$
}

${ }^{++}$Institute of Anatomy, UZH University of Zurich, Instiute of Anatomy, Winterthurerstrasse 190, CH${ }^{+}$Paris Sorbonne Université, Muséum National d'Histoire Naturelle, UMR CNRS 7590, IRD, Institut de Minéralogie, de Physique des Matériaux et de Cosmochimie, IMPMC, 75005 Paris, France 
ABSTRACT: IONP commercialized for treatments of iron anemia or cancer diseases can be administered at doses exceeding 1 gram per patient, indicating their bio-compatibility when they are

25 prepared in the right conditions. Various parameters influence IONP biodistribution such as

26 nanoparticle size, hydrophobicity/hydrophilicity, surface charge, core composition, coating properties,

27 route of administration, quantity administered, and opsonization. IONP biodistribution trends include

28 their capture by the reticuloendothelial system (RES), accumulation in liver and spleen, leading to

29 nanoparticle degradation by macrophages and liver Kupffer cells, possibly followed by excretion in

30 feces. To result in efficient tumor treatment, IONP need to reach the tumor in a sufficiently large

31 quantity, using: i) passive targeting, i.e. the extravasation of IONP through the blood vessel irrigating

32 the tumor, ii) molecular targeting achieved by a ligand bound to IONP specifically recognizing a cell

33 receptor, and iii) magnetic targeting in which a magnetic field gradient guides IONP towards the tumor.

34 As a whole, targeting efficacy is relatively similar for different targeting, yielding a percentage of 35 injected IONP in the tumor of $5.10^{-4}$ to $3 \%, 0.1$ to $7 \%$, and $5.10^{-3}$ to $2.6 \%$ for passive, molecular, and 36 magnetic targeting, respectively. For the treatment of iron anemia disease, IONP are captured by the 37 RES, and dissolved into free iron, which is then made available for the organism. For the treatment of 38 cancer, IONP either deliver chemotherapeutic drugs to tumors, produce localized heat under the 39 application of an alternating magnetic field or a laser, or activate in a controlled manner a sono40 sensitizer following ultrasound treatment.

42 KEYWORDS: iron oxide nanoparticle, toxicity, pharmacokinetic, biodistribution, liver toxicity, kidney 43 toxicity, iron anemia. 


\section{ABBREVIATIONS:}

45 Admin. Route: Route of administration.

46 BBB: Selective semi-permeable membrane barrier that separates the circulating blood from the brain

47 and extracellular fluid in the central nervous system.

48 CKD: Chronic kidney disease.

49 CE marked: CE marked medical devices, such as those containing nanoparticles, are allowed for 50 commercialization in Europe.

51 CT: circulation time, i.e. the time required for IONP to flow between two given points;.

$52 \mathrm{t}_{1 / 2}$ : blood half-life, i.e. the time it takes for IONP to have their concentration decreased by a factor of 2

53 following their administration.

54 CTX: Cyclophosphamide.

55 DMSA: Dimercaptosuccinic acid

56 EMA: European Medicines Agency.

57 EPR: Enhanced permeability and retention effect is a mechanism enabling IONP to accumulate in tumor

58 tissue more than in normal tissues.

59 FDA: Food and drug agency in USA.

60 IONP: Iron oxide nanoparticles, composed of a maghemite or magnetite core surrounded by a coating

61 material, displaying superparamagnetic or ferrimagnetic magnetic behaviors, of sizes 1 to $100 \mathrm{~nm}$.

62 iv: intravenous.

63 MT: Magnetic targeting or application of a magnetic field gradient on IONP to target the tumor with 64 IONP.

65 MDT: Molecular drug targeting used to target a tumor.

66 MTO: Mitoxantrone.

67 MTX: Methotrexate.

68 MRI: Magnetic resonance imaging.

69 MW: Molecular weight. 
PVA: Polyvinyl alcohol.

$71 \%$ ID: Percentage of the injected dose that ends up in the tumor.

72 Quantity admin.: Quantity administered.

73 RES: Reticuloendothelial system is a network of cells and tissues, in blood, general connective tissue,

74 spleen, liver, lungs, bone marrow, and lymph nodes.

75 SPIO: Superparamagnetic iron oxide nanoparticles having a thermally unstable magnetic moment.

76 TA: Targeting agent used to target a tumor. 
79 In the medical field, IONP (iron oxide nanoparticles) have attracted much attention due to several of

80 their appealing properties such as: i) their faculty to efficiently release free iron in the organism and

81 fight against iron anemia disease, (Auerbach2017), ii) the coupling of their magnetic moment with an

82 external magnetic field that improves the quality of the contrast in magnetic resonance imaging (MRI),

83 (DiMarco2007), can yield efficient magnetic drug targeting (MDT), (Janko2013), or produce localized

84 heat in magnetic hyperthermia, (Perigo2015), iii) the absorption of laser light resulting in efficient

85 photothermal therapy, (Estelrich2018), iv) the binding of targeting agents, chemotherapeutic drugs, or

86 sonosentitzers, which can increase the quantity of IONP reaching the tumor and/or enhance anti-tumor

87 activity, (Gobbo2015). Figure 1 summarizes these various medical applications of IONP. Although

88 belonging to a specific category of nano-product, IONP are characterized by a series of different

89 physico-chemical properties: i) amorphous or crystallized structures, (Phu2011), ii), multiple iron oxide

90 compositions and crystallographic structures, such as magnetite $\left(\mathrm{Fe}_{3} \mathrm{O}_{4}\right)$ or maghemite $\left(\mathrm{Fe}_{2} \mathrm{O}_{3}\right)$,

91 (Salazar2011), iii), different sizes, size distributions, and hydrodynamic diameter, typically comprised

92 between 1 and 100-500 nm, (Wu2008), iv), various shapes or geometries including isotropic ones such

93 as cubic and spherical, (Zhen2011), and elongated ones such as elliptical, (Freitas2015), v), various

94 surface charges, typically comprised between -40 and $30 \mathrm{mV}$, (Sakukhua2015), vi), magnetic properties

95 most commonly leading to superparamagnetism or ferrimagnetism with unstable or stable magnetic

96 moment, respectively, (Wu2015), vi), the presence of various coating materials, targeting agents,

97 sonosensitizers, and/or chemotherapeutic drugs surrounding the iron oxide core, (Laurent2008). In

98 general, it is possible to tune these properties to adjust IONP biodistribution and activity in the

99 organism, making these nanoparticles an excellent system to foresee efficient treatments of cancer and

100 iron anemia disease. Here, various IONP fabrication methods as well as the main properties of

101 commercialized or CE marked IONP preparations are first described. Second, IONP biodistribution

102 properties as well as the main parameters influencing them are presented. Third, the different types of

103 targeting strategies that enable IONP to reach the tumor in sufficiently large quantity to trigger anti- 
104 tumor activity are highlighted. They include passive targeting through the EPR (Enhanced permeability

105 and retention) effect as well as molecular and magnetic active targeting. Fourth, the mechanisms of

106 actions are explained. They involve the capture of IONP by the RES (reticuloendothelial system)

107 followed by the dissolution of IONP into free iron for the treatment of iron anemia disease. In cancer

108 treatment, they are due to the delivery of anti-cancer drug in the tumor, localized tumor heating under

109 the application of an external alternating magnetic field or laser, or controlled drug release in the tumor

110 following ultrasound exposure.

111 GENERAL FABRICATION METHODS AND PROPERTIES OF IRON OXIDE

112 NANOPARTICLES

113 To synthesize IONP, various chemical synthesis have been suggested, which involve: i) co-precipitation 114 by mixing ferrous and ferric salts in an aqueous medium, (Martínez-Mera2007), ii), electrochemistry 115 where an electric current is applied between an anode and a cathode introduced in an electrolyte, the 116 anode oxidizes metal ions of the electrolyte that are further reduced to metal by the cathode with the 117 help of stabilizers, (Khan2000, Ramimoghadam2014), iii), flow injection syntheses by mixing reagents

118 under laminar flow regime in a capillary reactor, (Salazar2006), iv), hydrothermal reactions in which 119 mixed metal hydroxides can be autoclaved to produce nanoparticle powders, (Wan2005), v), laser 120 pyrolysis where a laser heats a mixture of iron precursors and a flowing mixture of gas, (21 121 Verdaguer1998), vi), high temperature reaction of polyol with an iron source, (Cai2007), vii), sol-gel

122 methods in which precursors undergo hydroxylation and condensation to yield nanometric particles

123 (sol), followed by condensation and polymerization to produce a three-dimensional metal oxide network

124 (wet gel), ending by a heating process that results in a crystallized structure, (Albornoz2006), viii), 125 sonolysis or thermolysis involving the decomposition or collapse of organometallic precursors such as 126 ferrous salts, (Osuna1996), ix), spray pyrolysis in which solutions of ferric salts and a reducing agent in 127 organic solvent is sprayed in reactors leading to the condensation of the aerosol solute and solvent 128 evaporation, (Pecharroman1994). 
129 Whereas IONP are predominantly composed of iron oxide, another material, which is often designated

130 as coating material, either surrounds the iron oxide core of IONP or is mixed with the iron oxide. Such

131 material is used to maintain IONP stability and enable its safe administration. A large number of

132 different coating materials have been added at the same time or following the fabrication of IONP core,

133 such as polysaccharides (Dias2011), acids (Laurent2008, Sahoo2005, boyer2010), polymers

134 (Boyer2010, Laurent2008, karimi2013), dendrimers (Walter2014, Parat2015), carbohydrate

135 (Mahmoudi2011), inorganic (Cui2014, Giakisikli2013) or organic materials (Gautier2013), metals

136 (Giakisikli2013), phosphates (Groult2014), silica (Mahmoudi2011, Alwi2012, Sun2005), dextran

137 (Osborne 2011, Hola2015, Berry2004), or PEG (Gupta2005, Hola2015). Furthermore, the coating

138 material usually contain a functional group, which is able to bind to the surface of IONP core, such as

$139 \mathrm{OH}$ (Hola2015, Boyer2010), $\mathrm{NH}_{2}$ (Hola2015), $\mathrm{COOH}$ (Hola2015), thiol (Fauconnier1997), phosphonate

140 (Basly2010), or phosphate (Groult2014). Functions such as $\mathrm{OH}, \mathrm{NH}_{2}, \mathrm{COOH}$, and thiol, usually give

141 rise to electrostatic interactions with the iron oxide, whereas phosphates yield covalent binding with the

142 iron oxide.

143 It goes beyond the scope of this article to describe in all details the various IONP physico-chemical

144 properties, such as IONP composition, size, charges, coating thickness, surface, interaction, geometry,

145 organization, distribution properties. The reader is redirected towards other excellent reviews on these

146 aspects, (Gupta2005, Laurent2008).

147 COMMERCIALIZED OR CE MARKED FORMULATIONS CONTAINING IRON OXIDE

148 NANOPARTICLES FOR THE TREATMENT OF IRON ANEMIA DISEASE OR CANCER

149 TREATMENT:

150 For patients suffering from iron anemia disease (IAD) for which orally administered iron does not lead

151 to sufficient efficacy, intravenous administration of the following IONP formulations have been

152 recommended and commercialized (Auerbach2017), (table 1): 
153 - Dexferrum (also designated as iron dextran injection), consisting of high molecular weight iron

154 dextran complex at a concentration of $50 \mathrm{mg} / \mathrm{mL}$ mixed in solution with sodium chloride for tonicity,

155 (Dexferrum monograph),

156 - Feraheme (also designated as Ferumoxytol or Rienso), consisting of non-stoichiometric

157 magnetite superparamagnetic iron oxide nanoparticles (SPIO) of 16-31 nm and $750 \mathrm{kDa}$ coated with

158 polyglucose sorbitol carboxymethylether, having a chemical formula $\mathrm{Fe}_{5874} \mathrm{O}_{8752}-\mathrm{C}_{11719} \mathrm{H}_{18682} \mathrm{O}_{9933} \mathrm{Na}_{414}$,

159 suspended in solution in the presence of mannitol at a $\mathrm{pH}$ of 6 to 8, an osmolality of $270-330 \mathrm{mOsm} / \mathrm{kg}$,

160 and a concentration of $30 \mathrm{mg} / \mathrm{mL}$, (Feraheme monograph),

161 - Ferrisat (also designated as Cosmofer, InFeD, iron dextran), made of a slightly viscous sterile

162 liquid complex of ferric hydroxide, dextran, and $0.9 \%$ sodium chloride, of $\mathrm{pH} 5.2-6.5$, and concentration

163 of $50 \mathrm{mg} / \mathrm{mL}$, (Infed monograph),

164 - Ferrlecit (sodium ferric gluconate complex in sucrose injection), made of a sodium salt of a

165 ferric iron gluconate complex in alkaline aqueous solution with approximately 20\% sucrose w/v (195

$166 \mathrm{mg} / \mathrm{mL}$ ) and $0.9 \% \mathrm{w} / \mathrm{v}$ benzyl alcohol as preservative, of molecular formula

$167\left[\mathrm{NaFe}_{2} \mathrm{O}_{3}\left(\mathrm{C}_{6} \mathrm{H}_{11} \mathrm{O}_{7}\right)\left(\mathrm{C}_{12} \mathrm{H}_{22} \mathrm{O}_{11}\right)_{5}\right], \mathrm{MW} 289-440 \mathrm{KDa}$, mixed in water at a $\mathrm{pH}$ of 7.7-9.7, concentration

168 of $12.5 \mathrm{mg} / \mathrm{mL}$, administered at a minimum cumulative dose of 1 gram of elemental iron administered

169 over several sessions, (Ferrlecit monograph).

170 - Monofer (also designated as iron isomaltose), made of iron(III) atoms chelated with

171 carbohydrate, mixed in solution of $\mathrm{pH}$ of 5-7 with $0.9 \%$ sodium chloride, having a structure resembling

172 that of ferritin, designed to prevent the toxicity of unbound inorganic iron(III), and administered at a

173 dose, which is: i), lower than $1 \mathrm{~g}$ for fast administration, i.e. within more than 15 minutes or, ii) larger

174 than $1 \mathrm{~g}$ for a slow administration, i.e. within more than 30 minutes, (Monofer monograph),

175 - Venofer ${ }^{\circledR}$ (iron sucrose injection), made of a complex of polynuclear iron (III)-hydroxide in

$17630 \% \mathrm{w} / \mathrm{v}$ sucrose without any preservative, of MW 34-60 kDa, proposed structural formula

$177\left[\mathrm{Na}_{2} \mathrm{Fe}_{5} \mathrm{O}_{8}(\mathrm{OH}) \cdot 3\left(\mathrm{H}_{2} \mathrm{O}\right)\right]_{\mathrm{n}} \cdot \mathrm{m}\left(\mathrm{C}_{12} \mathrm{H}_{22} \mathrm{O}_{11}\right)$, where $\mathrm{n}$ is the degree of iron polymerization and $\mathrm{m}$ is the 
178 number of sucrose molecules associated with the iron (III)-hydroxide, of iron concentration $20 \mathrm{mg} / \mathrm{mL}$,

$179 \mathrm{pH} \sim 10.5$, and osmolarity for injection $\sim 1.250 \mathrm{mOsmol} / \mathrm{L}$, (Venofer monograph),

180 - Nanotherm ${ }^{\circledR}$ is a CE marked IONP formulation, consisting of amino-silane coated SPIO of

181 diameter $15 \mathrm{~nm}$, dispersed in water at an iron concentration of $112 \mathrm{mg} / \mathrm{mL}$. It is designed to be

182 administered directly inside brain GBM tumor at a quantity of 200-600 $\mathrm{mg}$ of IONP and heated to 42-59

$183{ }^{\circ} \mathrm{C}$ by applying an alternating magnetic field of frequency $100 \mathrm{kHz}$ and strength $2.5-18 \mathrm{kA} / \mathrm{m}$, (Maier-

184 Hoff2007, Maier-Hoff2011).

185 PARAMETERS INFLUENCING THE BIODISTRIBUTION OF IRON OXIDE

\section{NANOPARTICLES}

187 The different parameters that influence IONP biodistribution properties in the organism, which are 188 summarized in Figure 2, are the followings:

189 - IONP size. It first has an impact on IONP blood half-life $\left(\mathrm{t}_{1 / 2}\right)$. Indeed, it was shown that $\mathrm{t}_{1 / 2}$ 190 decreases from $\mathrm{t}_{1 / 2} \sim 50 \mathrm{~min}$ at $20 \mathrm{~nm}$ down to $\mathrm{t}_{1 / 2} \sim 20 \mathrm{~min}$ at $85 \mathrm{~nm}$. (Kooi2003, Beaumont2009).

191 Second, it influences IONP route of elimination. IONP larger than $200 \mathrm{~nm}$ were reported to be degraded

192 by macrophages located in the marginal red pulp zone of the spleen that phagocyte IONP. IONP with

193 sizes lying between $200 \mathrm{~nm}$ and 10-15 $\mathrm{nm}$ can avoid renal clearance, diffuse through liver or spleen

194 fenestrated sinusoids and be trapped in these organs through macrophage phagocytosis (Feng2018).

195 IONP degradation in the liver is essentially carried out by Kupffer cells or hepatocytes, (Arami2015).

196 IONP captured in the liver are usually internalized by pinocytosis and degraded there, (Huang2010).

197 IONP smaller than 10-15 $\mathrm{nm}$ were reported to be captured and degraded by the kidney. The kidney

198 fenestrae act as filters that only allow IONP smaller than $\sim 10-15 \mathrm{~nm}$ to leave the bloodstream and get

199 rapidly excreted from the body. Third, when IONP are used to treat an individual with a tumor, their

200 size determines their ability to enter (or not) the tumor through the enhanced permeability and retention

201 (EPR) effect. Small IONP can more efficiently than larger ones extravasate from the tumor blood

202 vessels by the EPR effect and diffuse in the tumor. The EPR effect is reported to occur for IONP with a 
203 size lower than $\sim 200-300 \mathrm{~nm}$ above which NP size becomes significantly larger than the size of the

204 blood vessel holes that irrigate the tumor, (Wang2017).

205 IONP hydrophobicity/hydrophilicity. Hydrophobic IONP have a shorter circulation time (CT)

206 than hydrophilic ones since plasma proteins can more easily adsorb at their surface, yielding their

207 recognition by the reticuloendothelial system (RES), and removal from blood circulation, (Tong2010).

208 The core of IONP can be coated with hydrophilic molecules such as PEG to reduce opsonization and

209 increase IONP CT.

210 IONP surface charge. It determines the efficacy of: i), adsorption of plasma proteins at IONP

211 surface leading to IONP recognition and capture by these cells, (Sakulkhu2014), ii), binding of IONP to

212 non-targeted cells yielding nonspecific IONP internalization, (Bachmann2002). Since both of these

213 mechanisms are enhanced for positively charged IONP, these IONP should yield a faster clearance

214 compared with negatively or neutrally charged IONP, although, to the author knowledge, this has not

215 been firmly demonstrated experimentally.

216 IONP core composition (maghemite versus magnetite). Since degree of oxidation is relatively

217 similar between maghemite and magnetite, it is uncertain that it has a real impact on IONP

218 biodistribution profile.

219 IONP coating. IONP are coated to enhance their stability, enable their administration, prevent

220 IONP capture by the immune system, or target specific organs. The strength of the interactions between

221 coating and core of IONP determines for how long IONP coating remains associated with the IONP

222 core in vivo, i.e. coating adsorption yields more rapid coating detachment than covalent binding of the

223 coating, (Arami2015). A general relation between IONP half-life values $\left(\mathrm{t}_{1 / 2}\right)$ and coating type can't

224 easily be deduced from experimental data due to the large variation of $t_{1 / 2}$ values reported for the same

225 coating material, i.e. $6 \mathrm{~min}$ to $21-30 \mathrm{~h}$ for dextran, 7 to $8 \mathrm{~h}$ for chitosan, $45 \mathrm{~min}$ to $62 \mathrm{~h}$ for PEG, 8 to 36

226 min for citrate, (Arami2015). The distribution in $t_{1 / 2}$ values may be attributed to different coating

227 thicknesses or types of interaction with IONP core observed for the same coating material. A specific

228 coating (inoleic acid, lactobionic acid, PEG, dextran, CMD) can prevent IONP opsonization and capture 
229 by macrophages, and enable IONP to reach the liver or spleen, (Arami2015). Among the different types

230 of coatings, PEG has been the most widely used because of its stabilizing property via steric hindrance,

231 which prevents interaction with blood and serum proteins.

232 IONP administration route. IONP injected: i), by inhalation, intrapulmonary, intratracheal, or

233 in intranasal route led to IONP retention in the lung without significant adverse effects (Lewinski2013),

234 ii) intravenously resulted in IONP capture by the RES as well as accumulation and/or excretion through

235 liver, spleen, and/or kidney depending on IONP size, (Arami2015), iii), intradermally yielded IONP

236 accumulation in regional lymph nodes, (Longmire2008), iv), orally led to IONP localization in the

237 gastrointestinal (GIT), where IONP with a specific coating can overcome the acidic environment of

238 GIT, diffuse through the liver without capture by Kupffer cells, and enter the general blood circulation

239 system, (Arami2015), v), intra-peritoneal resulted in IONP distribution in liver, lymph nodes and lung,

240 (Pham2018), vi), subcutaneously facilitated high tumor uptake, (Reddy2005), vii) intratumorally

241 resulted in IONP either rapidly leaving the tumor 3 hours following injection to migrate to the bone

242 (Zadnik2014) or remaining in the tumor more than 29 hours following injection (Kossatz2015).

243 - Quantity of IONP administered in the organism. When the quantity of IONP administered

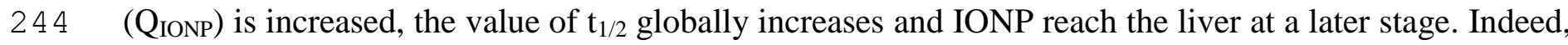
245 as Q Q ${ }_{\text {IONP }}$ increased from $0.0145-0.224 \mathrm{mg} / \mathrm{kg}$ to $11-15 \mathrm{mg} / \mathrm{kg}, \mathrm{t}_{1 / 2}$ was reported to globally increase from

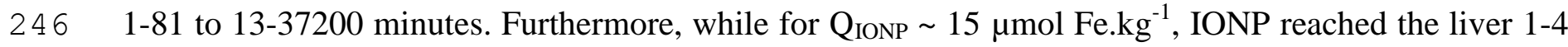

$247 \mathrm{~h}$ following IONP injection, they accumulated in this organ at a later stage for QIONP $\sim 150 \mu \mathrm{mol} \mathrm{Fe.kg-}$

248 , i.e. 8-24 h following IONP administration (Arami 2015).

249 IONP geometry. Indeed, it was reported that nanoparticles with a large length to width aspect 250 ratio, (Geng2007), possess a longer blood circulation time than their spherical counterparts,

251 (Petros2010). IONP geometry could also possibly determine the organ in which nanoparticles diffuse,

252 with elongated and spherical nanoparticles accumulating predominantly in lymph nodes, (Park2008),

253 and liver, (Zhao2013), respectively. 
- IONP opsonization. It is another important factor determining the toxicity/biodistribution of

255 these nanoparticles. Opsonization mechanism, which was reported to occur both at IONP core and 256 coating surfaces, seems to depend on: i), protein molecular weight and IONP size with heavier proteins

257 seemingly adsorbing onto larger IONP, (Sakulkhu2014), ii), charges with proteins adsorbing onto IONP 258 surface of opposite charge as that of proteins. For IONP coated with dextran, cationic plasma proteins 259 such as histidine-proline rich glycoprotein (HPRG) and high molecular weight kininogen (HMWK) 260 were observed to bind to anionic magnetite cores, (Simberg2009), while immunoglobulins (IgG) and 261 mannanbinding lectins (MBL) were observed to interact with the cationic dextran coating, 262 (Simberg2009). In general, opsonized IONP were shown to yield longer $\mathrm{t}_{1 / 2}$, CT, and/or clearance 263 values, (Arami2015).

\section{IONP BIODISTRIBUTION AND PHARMACOKINETICS}

265 IONP biodistribution properties depend on the physiological barriers that they encounter, their faculty to

266 cross (or not) these barriers as well as the chosen administration route (see previous section). 267 Biodistribution properties are summarized in table 2 for IONP administered by intravenous, intra268 gastric, or intraperitoneal route, to mice, rats, and pig, at a dose comprised between 0.5 to $2000 \mathrm{mg} / \mathrm{Kg}$.

269 When IONP are injected intravenously, they can be captured by white blood cells such as monocytes 270 and residential tissue macrophages, and accumulate in liver and spleen, (Feng2018). Redistribution in 271 these organs depends on the following parameters: i), the time following administration, i.e. it was 272 observed to increase during 5-15 hours following IONP injection and then decrease afterwards 273 (Azadkbakht2017), ii), the size of IONP, the smallest (10 nm) and largest (40 nm) IONP were reported 274 to accumulate predominantly in the liver and spleen, respectively (Yang2015), iiii), the quantity of 275 IONP administered with IONP possibly distributing in spleen after saturation of the liver, (Remya2016).

276 In the liver, IONP are phagocytized by Kupffer cells, which degrade and metabolize them partly or fully 277 in dissolved iron and/or in a protein-iron complex, called ferritin, possibly with the help of liver 278 hepatocytes (Gu2012, Briley-Saebo2004). When Kupffer cells are saturated by a too large quantity of 279 IONP, (Arami2015), IONP could be degraded by spleen macrophages. IONP can be found in smaller 
280 quantity than in spleen and liver in other organs such as lung, kidney, heart, bladder, muscle, ovary,

281 colon, muscle, pancreas, intestine, stomach, and uterus, (table 2). When IONP enter an organ, they

282 ultimately may diffuse to the lymph nodes surrounding it, (Thorek2006). Under specific conditions in

283 terms of IONP size, coating, and presence of a specific targeting compound, IONP have been reported

284 to cross several physiological barriers such as the blood brain, (Huang2016), placental (Muller2018), or

285 skin barrier (Musazzi2017). Furthermore, IONP can also target tumors following intravenous

286 administration, either through passive targeting also called enhanced permeability retention (EPR)

287 effect, (Maeda2010), or active targeting using a compound attached to IONP such as peptides (e.g.

288 chlorotoxin, RGD, CREKA, bombesin, $\left.\mathrm{F}_{3}, \mathrm{~A}_{54}, \mathrm{LHRH}\right)$, antibodies (e.g. Anti-HER 2 , Anti-

289 EGFR/EGFRvIII), and small molecules (e.g. folate) that can specifically recognize tumor cells,

290 (Cole2011). Concerning IONP excretion mechanism, although it was suggest that the largest IONP end

291 up in liver, spleen and then feces while the smallest ones are eliminated through kidney and urines,

292 multiple IONP transformations in the organism can possibly yield a different behavior.

293 TARGETING MECHANISMES OF IRON OXIDE NANOPARTICLE

294 Passive targeting (EPR effect):

295 The efficacy of passive targeting, measured by estimating the percentage of injected IONP in tumors

296 resulting from passive targeting of various types of IONP (different charges, coatings, encapsulations,

297 compositions), following intravenous injection of $0.1-4 \mathrm{mg}$ of IONP to mice suffering from different

298 types of tumors, is summarized in table 3. The EPR effect is a consequence of angiogenesis, which leads

299 to highly proliferating endothelial cells with a low density, and to openings of $100-800 \mathrm{~nm}$ between

300 these cells. Nanoparticles, which are smaller than 100-800 $\mathrm{nm}$ can extravasate or diffuse from the blood

301 vessels into the tumor interstitium. On the one hand, the largest nanoparticle size for which the EPR

302 effect occurs seems to be $\sim 200 \mathrm{~nm}$, since nanoparticles larger than $200 \mathrm{~nm}$ could be captured by the

303 spleen or liver and not able to reach the tumor. On the other hand, nanoparticles smaller than $30 \mathrm{~nm}$

304 could diffuse back from the tumor to the blood vessel, and be eliminated by the MPS or kidneys,

305 (Sun2014). The range of nanoparticle sizes that yields the most efficient tumor retention is therefore 
306 comprised between 30 and $200 \mathrm{~nm}$. Other nanoparticle parameters can have an impact on EPR efficacy

307 such as: i), the shape of the nanoparticles with spherical nanoparticles apparently diffusing less

308 efficiently through the vascular wall than rod- and bar-shaped nanoparticles, ii) the sleath capacity of the

309 nanoparticles, provided for example by the presence of PEG molecules at nanoparticle surface, leading

310 to prolonged circulation half-life, less protein adsorption, reduction in clearance by the MPS, and thus

311 improved tumor accumulation, iii) the charge of nanoparticle with slightly negatively charged

312 nanoparticles escaping from macrophage endocytosis, and therefore more efficient accumulating in

313 tumor, (Sun2014). To be more efficient, passive targeting needs to overcome the following limitations:

314 i), the in-homogeneous distribution of blood vessels resulting from angiogenesis that yields non-uniform

315 permeability within the whole tumor, ii), its limited efficacy on small tumors or metastases that display

316 reduced angiogenesis, iii), its efficacy of tumor targeting leading to $0.0005-3 \%$ of injected IONP in

317 tumor (table 3) and to 20-30\% more nanoparticles in tumors compared with other organs,

318 (Kobayashi2014). While the EPR effect was reported to lack efficacy in some studies, (Wilhelm2016),

319 it was described as enabling nanoparticles to achieve much improved targeting efficacy compared with

320 other drugs in some other studies, (Golombek2018).

\section{Molecular targeting:}

322 Active targeting usually occurs after nanoparticles have diffused to the tumor by passive targeting, 323 making the efficacy of active targeting dependent on that of the EPR effect. The principle of active

324 targeting relies on interactions between a ligand attached to the nanoparticles and a receptor located at 325 cell surface. Examples of ligands are: i) various monoclonal antibodies, e.g. 610, L6, HER/Neu, A7, and

326 antibody to prostate specific membrane antigen, ii) transferrin, iii) various peptides , e.g. EPPT,

327 Chlorotoxin, F3, and CREKA, iv) folic acid and methotrexate, v) Herceptin, vi) RGD, vii) luteinizing

328 hormone releasing hormone (LHRM), which target: i) antigens of different tumor cells, ii) transferrin

329 receptor, iii) Underglycosylated mucin-1 antigen (uMUC-1), membrane-bound

330 matrixmetalloproteinase-2 (MMP-2), Surface-localized tumor vasculature, Clotted plasma proteins, iv)

331 folate receptor, v) Her-2/neu receptors, vi) $\alpha_{v} \beta_{3}$ integrins, and vii) LHRH receptor, respectively, 
332 (Peng2008). To be efficient, active targeting seems to require the combination of a rather larger number

333 of properties such as: a larger quantity of receptors on cancer than non-cancer cells, the availability of

334 receptors on cancer cell surface, the successful binding of ligands to receptors followed by

335 internalization of the complex ligand-IONP in cancer cells, an homogenous distribution of receptors

336 within the tumor, the availability of cancer cells used for in vitro assessment of ligand/receptor

337 interactions displaying similar properties than cancer cells found in a patient's tumor, a sufficiently

338 large fraction of tumor cells expressing a receptor specific to the used ligand. Table 4 summarizes the

339 efficacy of active targeting reached by administering intravenously to mice suspensions containing

340 between 0.073 and $0.5 \mathrm{mg}$ of IONP combined with different types of targeting agents (TA), i.e. various

341 antibodies (PSMA antibody, anti-GD2 antibody, Trastuzufab, antibody fragment Ffab), biotin, folate,

342 and RGD. It was reported that the administration of IONP with TA increases the percentage of IONP in

343 tumor, e.g. the percentage of injected IONP increases from $1.4 \%$ without Trastuzufab to $3 \%$ with

344 Trastuzufab, (Dong2015). Interestingly, such improvement was observed for IONP of the lowest size

$345(30 \mathrm{~nm})$, and not for those of $100 \mathrm{~nm}$, suggesting that as for the EPR effect, the efficacy of active

346 targeting may depend on nanoparticle size, (Dong2015). Another interesting study has shown that by

347 adding carboxy-methyl-dextran (CMD) at the surface of the nanoparticles, which increases IONP

348 circulation time, the efficacy of active targeting of IONP toward KB tumors increases from $4 \%$ using

349 IONP associated with Ffab to 7\% using IONP combined with Ffab and CMD. Due to the large number

350 of parameters that needs to be under control to make active targeting efficient, it is unsurprising that

351 various studies report very different efficacy for active targeting (table 4). As a whole, it however

352 appears that active targeting is promising and therefore deserves to be tested on humans.

\section{Magnetic targeting:}

354 The principle of magnetic targeting relies on the application of a magnetic field gradient that results in a

355 magnetic force, F, which is sufficiently strong to drive IONP towards the tumor, usually in an opposite

356 direction from that of the blood flow. Using a simplified approach that does not take into consideration

357 the complexity of biological systems but gives an idea of the parameters onto which the magnetic force 
358 depends, it was suggested that: $F=M_{S} \cdot V \cdot \nabla B$, where $M_{S}$ and $V$ are the saturating magnetization and

359 volume of IONP, respectively, and $\nabla \mathrm{B}$ is the magnetic field gradient applied on IONP,

360 (Bietenbeck2016). According to this relation, the magnetic force is the strongest when the saturating

361 magnetization, volume of nanoparticles, and $\nabla B$ reach the largest values. In fact, although the values of

362 these three parameters should be large enough for magnetic targeting to be efficient, they can't exceed

363 certain values, e.g. first the volume of IONP should remain below the volume at which IONP switch

364 from a single to a multi domain magnetic behavior, second the saturating magnetization may be

365 increased by doping iron oxide nanoparticles with various materials such as cobalt but these materials

366 are usually toxic and can't easily be used for medical application, third too large magnetic gradients

367 should be avoided since they could also possibly prevent efficient targeting. The efficacy of magnetic

368 targeting further depends on other parameters such as blood flow or viscosity, and SPION concentration

369 in the blood. Regarding the properties of the magnetic field required to reach efficient magnetic

370 targeting, most studies report the use an external and static magnetic field to guide IONP toward the

371 tumor region, whose strength is between 0.2 and $0.6 \mathrm{~T}$. The value of the magnetic field gradient, which

372 is more directly linked to the efficacy of magnetic targeting than that of the magnetic field strength, is

373 usually not given. One study mentions the use of a magnetic field gradient of $100 \mathrm{~T} / \mathrm{m}$ to drive IONP

374 through arteries, (Bietenbeck2016). Interestingly, efficient magnetic targeting was observed for different

375 durations of application of the magnetic field, which was typically comprised between 30 min,

376 (Aguiar2017) and 48 h (Estelrich2015). Practically, for efficient magnetic targeting, different types of

377 magnets such as neodymium magnet or electromagnet, (Aguiar2017), can be attached at the surface of

378 the skin, located above the tumor of the treated animals. Table 5 summarizes the efficacy of magnetic

379 targeting of various types of IONP (different coatings, charges, compositions) injected intravenously or

380 intra-arterially to mice or rats at a dose comprised between $0.3 \mathrm{mg}$ and $4 \mathrm{mg}$ per animal, under the

381 application of a magnetic field usually orientated in the direction of the tumor of strength comprised

382 between $0.32 \mathrm{~T}$ and $1.2 \mathrm{~T}$. It was shown in several studies that magnetic targeting improves the efficacy

383 of targeting, i.e. the percentage of injected IONP ending up in the tumor increases from $5.10^{-3}$ to $5.10^{-}$ 
$384{ }^{2} \%$ for G100 starch coated IONP targeting 9L glioma tumor, from 2 to $6 \%$ for IONP encapsulated in

385 nanocapsule targeting CT-26 colon tumor, from 0.1 to $0.5-0.8 \%$ for IONP coated with amino groups

386 targeting C6 glioma tumors, from 3 to $7 \%$ for IONP embedded in nano-bubbles targeting CT26 colon

387 tumors, and from 5 to $12 \%$ for IONP of composition ZnMnFeO targeting 4T1 tumor (table 5).

388 Interestingly, it was also reported that several IONP properties can further improve the efficacy of

389 magnetic targeting such as: i) the application of focused ultrasound (FUS) for the targeting of C6 glioma

390 brain tumors that possibly favors the diffusion of IONP to brain tumor by opening the blood brain

391 barrier, resulting in an increase in the percentage of injected IONP in the tumor from $2 \%$ using MT

392 without FUS to $6 \%$ using MT with FUS, ii) the coating surrounding IONP that can increase the

393 circulation time of IONP or contribute to an active targeting mechanism, resulting in an increase of the

394 percentage of injected IONP in the tumor from 1\% using IONP without a specific coating to $3 \%$ using

395 IONP coated with $\beta$-glucosidase that targets amygdalin and furthermore to $6.5 \%$ using IONP coated

396 with both $\beta$-glucosidase and PEG (Zhou2014). As a whole, the percentage of injected IONP that ends

397 up in the tumor following magnetic targeting varies quite a lot depending on the tested condition and

398 lies between $5.10^{-3}$ and $2.6 \%$. Given the values of these percentages, the majority of IONP does not end

399 up in the tumor but in other parts of the organism, and one should therefore verify that despite the small

400 values of these percentages, IONP are located in a sufficiently large quantity in the tumor to be able to

401 trigger anti-tumor activity.

\section{MECHANISME OF ACTION OF IONP IN TREATMENT OF IRON ANEMIA DISEASE}

403 IONP can be used for the treatment of iron anemia disease, possibly associated with chronic kidney

404 disease (CKD), and combined (or not) with other drugs such as erythropoietin. They are usually

405 prescribed when oral administration of iron based drugs is not sufficiently efficient. IONP can be

406 administered using a typical minimum total dose of $1 \mathrm{~g}$ of elemental iron. Sequential sessions can be

407 used to increase the quantity of injected IONP. The mechanism of action of these IONP relies on the

408 capture of these nanoparticles by the RES, which is believed to separate iron from other materials

409 comprised in IONP (dextran for dexferrum and ferrisat, polyglucose sorbitol carboxymethylether for 
410 feraheme, gluconate for ferrlecit, carbohydrate for monofer, amono-silane for nanotherm) and then

411 make iron bio-available for the organism. These IONP were reported to mainly distribute in blood,

412 extravascular fluid, liver, spleen and bone marrow. Iron could be trapped and possibly slowly released

413 in the bone marrow, liver, and/or spleen, and then get bound to or form hemosiderin, ferritin, or

414 transferrin, which can store or transport iron in the organism. This treatment was also described as

415 increasing the hemoglobin concentration in the organism. These IONP are characterized by large $\mathrm{t}_{1 / 2}$

416 values, i.e. $\mathrm{t}_{1 / 2} \sim 59$ hours for dexferrum, $\mathrm{t}_{1 / 2} \sim 15$ hours for Feraheme, $\mathrm{t}_{1 / 2} \sim 5-20$ hours for Ferrisat, $\mathrm{t}_{1 / 2} \sim$

417 7-12 hours for Injectafter, $\mathrm{t}_{1 / 2} \sim 1-4$ days for Monofer, $\mathrm{t}_{1 / 2} \sim 6 \mathrm{~h}$ for Venofer, (monographs of these

418 various drugs). Iron originating from these IONP usually displays negligible elimination by the kidneys.

419 Other material than iron, such as IONP coating, can be excreted through urines and/or feces or be

420 metabolized. The low toxicity of these IONP was highlighted by large $\mathrm{LD}_{50}$ values in mice, e.g. above

$421500 \mathrm{mg} / \mathrm{kg}$ (Monogr. Dexferrum).

422 IONP FOR DELIVERY OF ANTI-CANCER DRUGS IN THE ABSENCE OF AN EXTERNAL

\section{SOURCE OF EXCITATION}

424 First, IONP may be used to increase the probability of success of cancer gene therapy. In this case,

425 IONP can be coated with polymers, such as PEI, PEG, or chitosan, or made positively charged to bind

426 IONP with negatively charged nucleic acids, belonging either to DNA plasmids or to siRNA. The use of

427 IONP favors cellular internalization of DNA or siRNA, which further promotes transfection of DNA or

428 diffusion of siRNA in the cytoplasm followed by the inhibition of mRNA translation. In this way, the

429 normal behavior of cells could be restored by delivering DNA plasmids that can replace damaged genes

430 or siRNA that can prevent the expression of oncogenes, (Kievit2011).

431 Second, another application of IONP is the treatment of cancer by protein therapy. IONP can be 432 associated or linked to proteins to favor the antitumor mechanisms such as: i) the blocking of cell

433 surface receptors by using for example III (EGFRvIII) antibody that inhibit the cellular receptor 434 EGFRvIII, (Hadjipanayis2010), ii) CTX that decreases tumor cell proliferation, (Velseh2009), iii) 435 Cytochrome $\mathrm{c}$ that favors tumor cell apoptosis, (Santra2010), iv) interferon gamma (IFN $\gamma$ ) that triggers 
436 an anti-tumor immune activity, (Mejias2008). Compared with the use of free proteins (without IONP),

437 proteins associated with IONP should be less easily metabolized or cleared, be delivered more

438 efficiently to cancer cells, be protected from protease degradation, or more efficiently interact with parts

439 of cancer cells such as cell receptors by being located on IONP surface.

440 Third, IONP can enhance chemotherapy efficacy. As for gene and protein therapy, the underlying

441 mechanism relies on enhanced interaction between chemotherapeutic drugs and cells by linking these

442 drugs to IONP. By using IONP, chemotherapeutic drugs can have a better access to several parts of the

443 cells such as the cell nucleus to inhibit DNA replication, or mitochondria to prevent mitochondrial

444 activity. As an example, IONP conjugated to the anti-cancer drug MTO was administered intra-arterial

445 into rabbits, leading to drug accumulations in the tumor, complete tumor remissions, and to an apparent

446 cure among $30 \%$ of treated animals, (Tietze2013).

447 IONP and chemotherapeutic drugs can be linked together in different ways, (El-Boubbou2018), i.e. 448 through:

449 - Electrostatic, dipole-dipole, or van der Waals forces interactions between drugs and IONP, 450 resulting in IONP-drug complexes that are relatively simple to fabricate, prevent drug covalent 451 modification, and enable a control of drug delivery in the desired target of the organism,

452 - Drug encapsulation, e.g. by coating IONP core with a porous material such as silica, in which 453 drugs can be inserted, or by making phospholipid bilayers inside which IONP can be inserted, 454 preventing drug degradation, limiting drug side effects, and yielding controlled drug release.

455 - Covalent binding between IONP and drugs, e.g. using amine functionalized IONP that are 456 covalently conjugated to MTX, and enable drug release at an acidic $\mathrm{pH}$ of 2, (Kohler2005).

457 Compared with non-covalent bindings, covalent ones present both advantages and drawbacks. On the 458 one hand, they are very strong and can usually more efficiently resist physiological disturbance and 459 therefore yield a larger life time in the bloodstream. On the other hand, they can be non-biocompatible 460 depending on the chemicals used for the binding, non-cleavable after IONP have reached their target, or 461 enable only a small quantity of drugs attached to each IONP. 

SOURCE OF EXCITATION

464 The most widely used energy source to excite IONP has been the alternating magnetic field, in a treatment method called magnetic hyperthermia, (Obaidat2015, Chang2018, Giustini2010, Perigo2015). When IONP are exposed to such magnetic field, it either produces the rapid inversion of the magnetic 467 moment or physical rotation of IONP. Both moderate heating, at typically $41-46{ }^{\circ} \mathrm{C}$, and other non468 thermal effects, such as nanoparticles movements, have been reported to result from such excitation and 469 yield anti-tumor activity. Typical values of the magnetic field strength and frequency that need to be 470 applied to produce efficient magnetic hyperthermia are larger than 5-20 mT and 50-100 kHz, 471 respectively. In general, the strength and frequency of the magnetic field should remain below $20 \mathrm{mT}$ 472 and $100 \mathrm{kHz}$ to avoid non-localized heating that can occur outside of the nanoparticle regions, due to 473 Foucault currents produced by AMF of large strength and frequency. IONP have been administered 474 intra-tumorally or intravenously to treat different types of mouse tumors, and produced anti-tumor 475 activity, (Hayashi2013, Huang2013). Clinical trials are ongoing on patients suffering from glioblastoma 476 to evaluate the efficacy of this treatment, (Maier-Hoff2007, Maier-Hoff2010).

477 The laser is another excitation source that can be applied on IONP to heat the tumor. A laser wavelength 478 of $808 \mathrm{~nm}$, which yields minimal laser absorption by tissues, as well as a laser power density of 479 typically $1-5 \mathrm{~W} / \mathrm{cm}^{2}$, were reported to yield efficient heat production by IONP, (Esterlich2018). As an 480 example of the efficacy of such treatment, when C6 tumors were subcutaneously grown under the skin 481 of mice and injected with $0.2 \mathrm{mg}$ of IONP followed by 5 minutes tumor laser exposure $(825 \mathrm{~nm}, 1.5$ $482 \mathrm{~W} / \mathrm{cm}^{2}$ ), it prevented tumor growth, (Wang2018).

483 In the case of ultrasound tumor treatment, it was also suggested to use IONP combined with a 484 sonosensitizer to trigger anti-tumor activity, (Qian2016). Indeed, when SkBr3 breast tumors of $100 \mathrm{~mm}^{3}$ 485 were injected intravenously with $0.4 \mathrm{mg}$ of IONP conjugated with PEG and Rose Bengal sonosensitizer 486 followed first by the application of a magnetic field on IONP to enhance tumor targeting and then by 487 tumor ultrasound irradiation at $2 \mathrm{~W}$ during 60 seconds $24 \mathrm{~h}$ post injection, it led to an increase of the 
488 tumor temperature from $31{ }^{\circ} \mathrm{C}$ to $48{ }^{\circ} \mathrm{C}$ and to a decrease of tumor size within one month following

489 treatment (Chen2016).

\section{CONCLUSION}

491 In this review, the different methods of IONP fabrication as well as the various IONP physico-chemical

492 properties are briefly presented. IONP are currently commercialized or CE marked for treatments of 493 iron anemia or cancer diseases. For these applications, they can be administered to patients, at doses that 494 can exceed 1 gram per patient in some specific conditions.

495 The different parameters that influence iron oxide nanoparticle toxicity and biodistribution are:

496 - IONP size. It that has an impact on: i) $\mathrm{t}_{1 / 2}$ values, i.e. $\mathrm{t}_{1 / 2}$ increases with decreasing IONP sizes, 497 ii), the route of elimination, i.e. IONP > $200 \mathrm{~nm}$ are degraded in spleen, $10 \mathrm{~nm}<\mathrm{IONP}<200 \mathrm{~nm}$ are 498 eliminated in liver and spleen, while IONP $<10 \mathrm{~nm}$ are excreted through kidney.

499 - IONP Hydrophobic/Hydrophilic properties. Hydrophobic IONP yields a shorter circulation 500 time than hydrophilic ones.

501 - IONP surface charge. Positively charged IONP have a faster clearance than negatively or 502 neutrally charged ones.

503 - IONP coating. IONP specific coating, such as PEG, can prevent nanoparticle capture by 504 macrophages.

505 - IONP administration route. It determines in which organ IONP distribute and how they are 506 eliminated.

507 Opsonization. When IONP are opsonized or when their quantity administered increases, it can 508 lead to an increase in $\mathrm{t}_{1 / 2}$ values.

509 Concerning the use of IONP for the treatment of iron anemia, it necessitates a sufficiently large IONP 510 circulation time to enables efficient IONP capture by the RES followed by IONP dissolution into free 511 iron. This can be achieved by choosing appropriate IONP properties, in particular IONP coating and 512 IONP size. With regard to cancer treatment with IONP, it necessitates that a sufficiently large quantity 
513 of IONP reaches the tumor. For that, different types of targeting strategies have been tested. Although

514 molecular and magnetic targeting do not seem to improve in all cases targeting efficacy compared with 515 passive targeting, it seems that the quantity of IONP in the tumor is sufficient to trigger anti-tumor 516 activity using IONP for the delivery of chemotherapeutic drugs in the tumor, localized heat in the tumor 517 following the application of an alternating magnetic field or laser, or the activation of a sonosensitizer 518 under ultrasound exposure.

519 ACKNOWLEDGMENT: We would like to thank the BPI ('banque publique d'investissement, 520 France"), the region of Paris ('Paris Région Entreprise, France'), the French Research Tax Credit 521 program ("'crédit d'impôt recherche”), the incubator Paris Biotech Santé, the ANRT (CIFRE 522 2014/0359, CIFRE 2016/0747, CIFRE 2013/0364, CIFRE 2015/976), the Eurostars programs 523 (Nanoneck-2 E9309 and Nanoglioma E11778), the AIR program ('aide à l'innovation responsable') 524 from the region of Paris (A1401025Q), the ANR ('Agence Nationale de la Recherche’) Méfisto, as 525 well as the Universities Paris 6 and Paris 11. We also would like to thank the Nomis Foundation and 526 Markus Reinhard for their support. 


\section{REFERENCES:}

529 Abdollah MRA, Carter TJ, Jones C, Kalber TL Rajkumar V, Tolner B, Gruettner C, Zaw-Thin, Baguña

530 Torres J, Ellis M, Robson M, Pedley RB, Mulholland P, de Rosales RTM, Chester KA. Fucoidan

531 Prolongs the Circulation Time of Dextran-Coated Iron Oxide Nanoparticles. ACS Nano 2018, 12:

532 1156-1169.

533 Aguiar MFDP, Mamani JB, Felix TK, Dos Reis RF, Da Silva HR, Nucci LP, Nucci-da-Silva MP,

534 Gamarra F. Magnetic targeting with superparamagnetic iron oxide nanoparticles for in vivo glioma.

$535 \quad$ Nanotechnol Rev 2017, 6: 449-472.

536 Albornoz C, Jacobo SE. Preparation of a biocompatible magnetic film from an aqueous ferrofluid. $J$.

537 Magn. Magn. Mat. 2006, 305: 12-15.

538 Al-Jamal KT, Bai J, Wang JTW, Protti A, Southern P, Bogart L, Heidari H, Li X, Cakebread A, Asker

539 D, Al-Jamal WT, Shah A, Bals S. Magnetic Drug Targeting: Preclinical in Vivo Studies, Mathematical

540 Modeling, and Extrapolation to Humans. Nano Lett. 2016, 16: 5652-5660.

541 Alwi R, Telenkov S, Mandelis A, Leshuk T, Gu F, Oladepo S, Michaelian K. Silica-coated super

542 paramagnetic iron oxide nanoparticles (SPION) as biocompatible contrast agent in biomedical

543 photoacoustics. Biomedical Optics Express. 2012, 3: 2500-2509.

544 Arami H, Khandhar A, Liggitt D, Krishnan KM. In vivo delivery, pharmacokinetics, biodistribution

545 and toxicity of iron oxide nanoparticles. Chem. Soc. Rev. 2015, 44: 8576-8607.

546 Auerbach M, Macdougall I. The available intravenous iron formulations: History, efficacy, and

547 toxicology. Hemadialysis International 2017, 21: S83-S92.

548 Azad BB, Banerjee SR, Pullambhatla M, Lacerda S, Foss CA, Wang Y, Ivkov R, Pomper MG.

549 Evaluation of a PSMA-targeted BNF nanoparticle construct. Nanoscale 2015, 7: 4432-4442.

550 Azadkbakht B, Afarideh H, Ghannadi-Maragheh M, Bahrami-Samani A, Yousefnia H. Absorbed doses

551 in humans from 188Re-Rituximab in the free form and bound to superparamagnetic iron oxide

552 nanoparticles: Biodistribution study in mice. Applied Radiation and Isotopes. 2018, 131: 96-102. 
553 Bachmann R, Conrad R, Kreft B, Luzar O, Block W, Flacke S, Pauleit D, Traber F, Gieseke J, Saebo K,

554 Schild H. Evaluation of a New Ultrasmall Superparamagnetic Iron Oxide Contrast Agent Clariscan, 555 (NC100150) for MRI of Renal Perfusion: Experimental Study in an Animal Model. Journal of magnetic 556 resonance imaging 2002, 16:190-195.

557 Baiu DC, Artz NS, McElreath MR, Menapace BD, Hernando D, Reeder SB, Grüttner C, Otto M. High 558 specificity targeting and detection of human neuroblastoma using multifunctional anti-GD2 iron-oxide 559 Nanoparticles. Nanomedicine 2015, 10: 2973-2988.

560 Basly B, Felder-Flesch D, Perriat P, Billotey C, Taleb J, Pourroy G, Begin-Colin S. Dendronized iron 561 oxide nanoparticles as contrast agents for MRI. Chem. Commun. 2010, 46: 985-987.

562 Beaumont M, Lemasson B, Farion R, Segebarth C, Rémy C, Barbier EL. Characterization of tumor 563 angiogenesis in rat brain using iron-based vessel size index MRI in combination with gadolinium-based 564 dynamic contrast-enhanced MRI. Journal of Cerebral Blood Flow \& Metabolism 2009, 29: 1714-1726.

565 Beckmann N, Cannet C, Babin AL, Blé FX, Zurbruegg S, Kneuer R, Dousset V. In vivo visualization of 566 macrophage infiltration and activity in inflammation using magnetic resonance imaging. WIREs 567 Nanomedicine and Nanobiotechnology 2009, 1:272-298.

568 Berry CC, Wells S, Charles S, Aitchison G, Curtis ASG. Cell response to dextran-derivatised iron oxide 569 nanoparticles post internalization. Biomaterials 2004, 25: 5405-5413.

570 Bietenbeck, M, Florian A, Faber C, Sechtem U, Yilmaz A. Remote magnetic targeting of iron oxide 571 nanoparticles for cardiovascular diagnosis and therapeutic drug delivery: where are we now? 572 International Journal of Nanomedicine 2016, 11: 3191-3203.

573 Boyer C, Whittaker MR, Bulmus V, Liu J, Davis TP. The design and utility of polymer-stabilized iron574 oxide nanoparticles for nanomedicine applications. NPG Asia Mater. 2010, 2: 23-30.

575 Briley-Saebo K, Bjornerud A, Grant D, Ahlstrom H, Berg T, Kindberg GM. Hepatic cellular 576 distribution and degradation of iron oxide nanoparticles following single intravenous injection in rats: 577 implications for magnetic resonance imaging. Cell Tissue Res 2004, 316: 315-323. 
578 Cai W, Wan J. Facile synthesis of superparamagnetic magnetite nanoparticles in liquid polyols. Journal 579 of Colloid and Interface Science 2007, 305: 366-370.

580 Chang D, Lim M, Goos JACM, Qiao R, Ng YY, Mansfeld FM, Jackson M, Davis TP, Kavallaris M. 581 Biologically Targeted Magnetic Hyperthermia: Potential and Limitations. Frontiers in Pharmacology 9: 582831.

583 Chen D, Jiang M, Li N, Gu H, Xu Q, Ge J, Xia X, Lu J. Modification of magnetic silica/iron oxide 584 nanocomposites with fluorescent polymethacrylic acid for cancer targeting and drug delivery. J. Mater. 585 Chem. 2010, 20: 6422-6429.

586 Chen YW, Liu TY, Chang PH, Hsu PH, Liu HL, Lina HC, Chen SY. A theranostic nrGO@MSN-ION 587 nanocarrier developed to enhance the combination effect of sonodynamic therapy and ultrasound 588 hyperthermia for treating tumor. Nanoscale 2016, 8: 12648-12657.

589 Chertok B, David AE, Huang Y, Yang VC. Glioma selectivity of magnetically targeted nanoparticles: A 590 role of abnormal tumor hydrodynamics. Journal of Controlled Release 2007, 122: 315-323.

591 Chertok B, David AE, Yang VC. Polyethyleneimine-modified iron oxide nanoparticles for brain tumor 592 drug delivery using magnetic targeting and intra-carotid administration. Biomaterials 2010, 31: 63175936324.

594 Cole AJ, David AE, Wang J, Galban CJ, Hill HL, Yang VC. Polyethylene glycol modified, cross-linked 595 starch-coated iron oxide nanoparticles for enhanced magnetic tumor targeting. Biomaterials 2011, 32: $596 \quad 2183-2193$.

597 Cui X, Belo S, Kruger D, Yan Y, Rosales RTM, Jeuregui-Osoro M, Ye H, Su S, Mathe D, Kovacs N, 598 Horvath I, Semjeni M, Sunassee K, Szigeti K, Green MA, Blower PJ. Aluminium hydroxide stabilised $599 \mathrm{MnFe}_{2} \mathrm{O}_{4}$ and $\mathrm{Fe}_{3} \mathrm{O}_{4}$ nanoparticles as dual-modality contrasts agent for MRI and PET imaging. $600 \quad$ Biomaterials 2014, 35: 5840-5846.

601 Dan M, Cochran DB, Yokel RA, Dziubla TB. Binding, Transcytosis and Biodistribution of Anti602 PECAM-1 Iron Oxide Nanoparticles for Brain-Targeted Delivery. Plos One 2013, 8: e81051. 
603 Dias AMGC, Hussain A, Marcos AS, Roque ACA. A biotechnological perspective on the application of 604 iron oxide magnetic colloids modified with polysaccharides. Biotechnology Advances 2011, 29: 142605155.

606 DiMarco M, Guilbert I, Port M, Robic C, Couvreur P, Dubernet C. Colloidal stability of ultrasmall 607 superparamagnetic iron oxide (USPIO) particles with different coatings. International Journal of $608 \quad$ Pharmaceutics 2007, 331: 197-203.

609 Dong CN, Tate JA, Kett WC, Batra J, Demidenko E, Lewis LD, Hoopes PJ, Gerngross TU, Griswold 610 KE. Tumor Cell Targeting by Iron Oxide Nanoparticles Is Dominated by Different Factors In Vitro 611 versus In Vivo. PLOS one 2015, DOI:10.1371/journal.pone.0115636.

612 Edge D, Shortt CM, Gobbo OL, Teughels S, Prina-Mello A, Volkov Y, MacEneaney P, Radomski MW, 613 Markos F. Pharmacokinetics and bio-distribution of novel super paramagnetic iron oxide nanoparticles 614 (SPIONs) in the anaesthetized pig. Clinical and Experimental Pharmacology and Physiology 2016, 43: $615319-326$.

616 El-Boubbou K. Magnetic iron oxide nanoparticles as drug carriers: preparation, conjugation and 617 delivery. Nanomedicine 2018, DOI:10.2217/nnm-2017-0320.

618 El-Kharrag R, Amin A, Hisaindee S, Greish Y, Karam S. Development of a therapeutic model of 619 precancerous liver using crocin-coated magnetite nanoparticles. International journal of oncology 2017, $620 \quad 50: 212-222$.

621 Elmore S. Apoptosis: A Review of Programmed Cell Death. Toxicol Pathol. 2007, 35: 495-516.

622 Escamilla-Rivera V, Uribe-Ramirez, Gonzalez-Pozos S, Lozano O, Lucas S, Vizcaya-Ruiz A. Protein 623 corona acts as a protective shield against Fe3O4-PEG inflammation and ROS-induced toxicity in human 624 macrophages. Toxicology Letters 2016, 240: 172-184.

625 Estelrich J, Busquets MA. Iron Oxide Nanoparticles in Photothermal Therapy. Molecules 2018, 23: 6261567. 
627 Fan C-H, Ting C-Y, Lin HJ, Wang CH, Liu HL, Yen TC, Yeh CK. SPIO-conjugated, doxorubicin-

628 loaded microbubbles for concurrent MRI and focused-ultrasound enhanced brain-tumor drug delivery.

629 Biomaterials 2013, 34: 3706-3715.

630 Fan Y, Li C, Li F, Chen D. pH-activated size reduction of large compound nanoparticles for in vivo

631 nucleus-targeted drug delivery. Biomaterials 2016, 85: 30-39.

632 Fauconnier N, Pons JN, Roger J, Bee A. Thiolation of Maghemite Nanoparticles by Dimercaptosuccinic

633 Acid. Journal of colloid and interface science 1997, 194: 427-433.

634 Feng Z, Zhao G, Yu L, Gough D, Howell SB. Preclinical eYcacy studies of a novel nanoparticle-based

635 formulation of paclitaxel that out-performs Abraxane. Cancer Chemother Pharmacol 2010, 65:923-930.

636 Feng Q, Liu Y, Huang J, Chen K, Huang J, Xiao K. Uptake, distribution, clearance, and toxicity of iron 637 oxide nanoparticles with different sizes and coatings. Scientific reports 2018, 8:2082.

638 Fernández-Bertólez N, Costa C, Brandao F, Kilic G, Teixeira JP, Pasaro E, Laffon B, Valdiglesias V. 639 Neurotoxicity assessment of oleic acid-coated iron oxide nanoparticles in SH-SY5Y cells. Toxicology $640 \quad 2018,406-407: 81-912018$.

641 Freitas J, Branco RM, Lisboa IGO, Costa TP, Campos MGN, Junior MJ, Marques RFC. Magnetic 642 Nanoparticles Obtained by Homogeneous Coprecipitation Sonochemically Assisted. Materials 643 Research. 2015, 18: 220-224.

644 Gautier J, Allard-Vannier E, Hervé-Haubert K, Soucé M, Chourpa I. Design strategies of hybrid 645 metallic nanoparticles for theragnostic applications. Nanotechnology 2013, 24:432002.

646 Geng Y, Dalhaimer P, Cai S, Tsai R, Tewari M, Minko T, Discher DE. Shape effects of filaments 647 versus spherical particles in flow and drug delivery. Nat Nanotechnol. 2007, 2: 249-255.

648 Giakisikli G, Anthemidis AN. Magnetic materials as sorbents for metal/metalloid preconcentration 649 and/or separation. A review. Analytica Chimica Acta 2013, 789:1-16.

650 Giustini AJ, Ivkov R, Hoopes PJ. Magnetic nanoparticle biodistribution following intratumoral 651 administration. Nanotechnology 2011, 22: 345101. 
652 Gobbo OL, Sjaastad K, Radomski MW, Volkov Y, Prina-Mello A. Magnetic Nanoparticles in Cancer

653 Theranostics. Theranostics 2015, 5: 1249-1263.

654 Golombek SK, May JN, Theek B, Appold L, Drude N, Kiessling F, Lammers T. Tumor Targeting via 655 EPR: Strategies to Enhance Patient Responses. Adv. Drug Deliv. Rev. 2018, 130: 17-38.

656 Groult H, Ruiz-Cabello J, Lechuga-Vieco AV, Mateo J, Benito M, Bilbao I, Martinez-Alcazar MP, 657 Lopez JA, Vasquez J, Herranz FF. Phosphatidylcholine-Coated Iron Oxide Nanomicelles for In Vivo 658 Prolonged Circulation Time with an Antibiofouling Protein Corona. Chem. Eur. J. 2014, 20: 1666265916671.

$660 \mathrm{Gu}$ L, Fang RH, Sailor MJ, Park J-H. In Vivo Clearance and Toxicity of Monodisperse Iron Oxide 661 Nanocrystals. ACS Nano. 2012, 6: 4947-4954.

662 Gupta AK, Gupta M. Synthesis and surface engineering of iron oxide nanoparticles for biomedical 663 applications. Biomaterials 2005, 26: 3995-4021.

664 Hadjipanayis CG, Machaidze R, Kaluzova M, Wang L, Schuette AJ, Chen H, Wu X, Mao H. EGFRvIII 665 antibody-conjugated iron oxide nanoparticles for magnetic resonance imaging-guided convection666 enhanced delivery and targeted therapy of glioblastoma. Cancer Res. 2010, 70: 6303-6312.

667 Hanot CC, Choi YS, Anani TB, Soundarrajan D, David AE. Effects of Iron-Oxide Nanoparticle Surface 668 Chemistry on Uptake Kinetics and Cytotoxicity in CHO-K1 Cells. Int. J. Mol. Sci. 2016, 17, 54; 669 doi:10.3390/ijms17010054.

670 Hayashi K, Nakamura M, Sakamoto W, Yogo T, Miki H, Ozaki S, Abe M, Matsumoto T, Ishimura1 K. 671 Superparamagnetic Nanoparticle Clusters for Cancer Theranostics Combining Magnetic Resonance 672 Imaging and Hyperthermia Treatment. Theranostics 2013, 3: 366-376.

673 Hola K, Markova Z, Zoppellaro G, Tucek J, Zboril R. Tailored functionalization of iron oxide 674 nanoparticles for MRI, drug delivery, magnetic separation and immobilization of biosubstances. 675 Biotechnology Advances. 2015, 33: 1162-1176.

676 Huang G, Diakur J, Xu Z, Wiebe LI. Asialoglycoprotein receptor-targeted superparamagnetic iron oxide 677 Nanoparticles. International Journal of Pharmaceutics 2008, 360: 197-203. 
678 Huang HS, Hainfeld JF. Intravenous magnetic nanoparticle cancer hyperthermia. International Journal 679 of Nanomedicine 2013, 8: 2521-2532.

680 Huang B, Zhang H, Gu L, Ye B, Jian Z, Stary C, Xiong X. Advances in Immunotherapy for 681 Glioblastoma Multiforme. Journal of Immunology Research 2017, Article ID 3597613.

682 Jain TK, Reddy MK, Morales MA, Leslie-Pelecky DL, Labhasetwar V. Biodistribution, Clearance, and 683 Biocompatibility of Iron Oxide Magnetic Nanoparticles in Rats. Molecular Pharmaceutics 2008, 5: $684 \quad 316-327$.

685 Janko C, Durr S, Munoz LE, Lyer S, Chaurio R, Tietze R, Von Lohneysen S, Shorn C, Herrmann M, 686 Alexiou C. Magnetic Drug Targeting Reduces the Chemotherapeutic Burden on Circulating Leukocytes. 687 Int. J. Mol. Sci. 2013, 14: 7341-7355.

688 Jia Z, Song L, Zang F, Song J, Zhang W, Yan C, Xie J, Ma Z, Ma M, Teng G, Gu N, Zhang Y. Active689 target T1-weighted MR Imaging of Tiny Hepatic Tumor via RGD Modified Ultra-small Fe3O4 690 Nanoprobes. Theranostics 2016, 6: 1780-1791.

691 Karathanasis E, Ghaghada KB. Crossing the barrier: Treatment of brain tumors using nanochain 692 particles. Wiley Interdiscip Rev Nanomed Nanobiotechnol. 2016, 8: 678-695.

693 Karimi Z, Karimi L, Shokrollahi H. Nano-magnetic particles used in biomedicine: Core and coating 694 materials. Materials Science and Engineering C 2013, 33: 2465-2475.

695 Khan HR, Petrikowski K. Anisotropic structural and magnetic properties of arrays of $\mathrm{Fe}_{26} \mathrm{Ni}_{74}$ 696 nanowires electrodeposited in the pores of anodic alumina. Journal of Magnetism and Magnetic 697 Materials 2000, 215-216: 526-528.

698 Kievit FM, Zhang M. Surface Engineering of Iron Oxide Nanoparticles for Targeted Cancer Therapy. 699 Accounts of chemical research 2011, 44: 853-862.

700 Kim JE, Shin JY, Cho MH. Magnetic nanoparticles: an update of application for drug delivery and 701 possible toxic effects. Arch Toxicol 2012, 86: 685-700.

702 Kobayashi H, Turbey B, Watanabe R, Choyke PL. Cancer Drug Delivery: Considerations in the 703 Rational Design of Nanosized Bioconjugates. Bioconjugate Chemistry 2014, 25: 2093-2100. 
704 Kohler N, Sun C, Wang J, Zhang M. Methotrexate-modified superparamagnetic nanoparticles and their

705 intracellular uptake into human cancer cells. Langmuir 2005, 21: 8858-8864.

706 Kooi ME, Cappendijk VC, Cleutjens KBJM, Kessels AGH, Kitslaar PJEHM, Borgers M, Frederick PM, 707 Daemen MJAP, Van Engelshoven JMA. Accumulation of Ultrasmall Superparamagnetic Particles of 708 Iron Oxide in Human Atherosclerotic Plaques Can Be Detected by In Vivo Magnetic Resonance 709 Imaging. Circulation 2003, 107:2453-2458.

710 Kossatz S, Granke J, Couleaud P, Latorre A, Aires A, Crosbie-Staunton K, Ludwig R, Dahring H, Ettelt

711 V, Lazzao-Carillo A, et al. Efficient treatment of breast cancer xenografts with multifunctionalized iron 712 oxide nanoparticles combining magnetic hyperthermia and anti-cancer drug delivery. Breast Cancer 713 Research 2015, 17:66.

714 Koziara M, Lockman PR, Allen DD, Mumper RJ. The blood-brain barrier and brain drug delivery. $J$ 715 Nanosci Nanotechnol. 2006, 6: 2712-2735.

716 Lee MJE, Veiseh O, Bhattarai N, Sun C, Hansen SJ, Ditzler S, Knoblaugh S, Lee D, Ellenbogen R, 717 Zhang M, Olson JM. Rapid Pharmacokinetic and Biodistribution Studies Using Cholorotoxin718 Conjugated Iron Oxide Nanoparticles: A Novel Non-Radioactive Method. PLOS One 2010, 5: e9536.

719 Leal MP, Munoz-Hernandez C, Berry C, Garcia-Martın ML. In vivo pharmacokinetics of $\mathrm{T}_{2}$ contrast 720 agents based on iron oxide nanoparticles: optimization of blood circulation times. RSC Adv. 2015, 5: $72176883-76891$.

722 Laurent S, Forge D, Port M, Roch A, Robic C, Vander Elst L, Muller RN. Magnetic Iron Oxide 723 Nanoparticles: Synthesis, Stabilization, Vectorization, Physicochemical Characterizations, and 724 Biological Applications. Chem. Rev. 2008, 108: 2064-2110.

725 Longmire M, Choyke PL, Kobayashi H. Clearance Properties of Nano-sized Particles and Molecules as 726 Imaging Agents: Considerations and Caveats. Nanomedicine 2008, 3: 703-717.

727 Maeda H. Tumor-Selective Delivery of Macromolecular Drugs via the EPR Effect: Background and 728 Future Prospects. Bioconjugate Chem. 2010, 21: 797-802. 
729 Mahmoudi M, Serpooshan V, Laurent S. Engineered nanoparticles for biomolecular imaging.

$730 \quad$ Nanoscale, 2011, 3, 3007-3026.

731 Maier-Hoff K, Rothe R, Scholz R, Van den Bent M.J, Taphoorn MJ, Janzer RC, Ludwin SK, Allgeier

732 A, Fisher B, Belanger K, Hau P, Brandes AA, Gijtenbeek J, Marosi C, Vecht CJ, Mokhtari K,

733 Wesseling P, Villa S, Eisenhauer E, Gorlia T, Weller M, Lacombe D, Cairncross JG, Mirimanoff RO.

734 Intracranial thermotherapy using magnetic nanoparticles combined with external beam radiotherapy:

735 Results of a feasibility study on patients with glioblastoma multiforme. J. Neuro-Oncology 2007, 81:

$736 \quad 53-60$.

737 Maier-Hoff K., Ulrich F, Nestler D, Niehoff H, Wust P, Tiesen B, Orawa H, Budach V, Jordan A.

738 Efficacy and safety of intratumoral thermotherapy using magnetic iron-oxide nanoparticles combined 739 with external beam radiotherapy on patients with recurrent glioblastoma multiforme. J. Neuro-Oncology

$740 \quad 2011,103: 317-324$.

741 Marcus M, Karni M, Baranes K, Levy I, Alon N, Margel S, Shefi. Iron oxide nanoparticles for neuronal

742 cell applications: uptake study and magnetic manipulations. J. Nanobiotechnol. 2016, 14:37.

743 Mei KC, Bai J, Lorrio S, Wang JTW, Al-Jamal KT. Investigating the effect of tumor vascularization on

744 magnetic targeting in vivo using retrospective design of experiment. Biomaterials 2016, 106: 276-285.

745 Mejias R, Costo R, Roca AG, Arias CF, Veintemillas-Verdaguer S, Gonzalez-Carreno T, del Puerto

746 Morales M, Serna CJ, Manes S, Barber DF. Cytokine adsorption/release on uniform magnetic

747 nanoparticles for localized drug delivery. J. Controlled Release 2008, 130: 168-174.

748 Mohamaddi MR, Malkovskiy AV, Jothimuthu P, Kim KM, Parekh M, Inayathullah M, Zhuge Y,

749 Rajadas J. PEG/Dextran double layer influence Fe ion release and stability of iron oxide nanoparticles.

$750 \quad$ Scientific reports 2018, 8: 4286.

751 Monograph of Dexferrum, NDA 40-024/S-022, American regent inc., Shirley, NY 11967, USA.

752 Monograph of Ferhaeme, AMAG Pharmaceuticals, Inc., Lexington, MA 02421, USA.

753 Monograph of Ferrlecit 2016, Submission Control No.: 195781, Sanofi-aventis Canada, 2905 Place

754 Louis-R.-Renaud, Laval, Quebec H7V 0A3, Canada. 
755 Monograph of Infed 2017, NDC 0023-6082-10, Allergan USA, Irvine, CA 92612, USA.

756 Monograph of Injectafter 2013, reference ID: 3347006. American regent, Inc. Shirley, NY 11967.

757 Monograph of Monofer 2017, Pharmacosmos A/S, Roervangsvej 30, DK-4300, Holbaek, Denmark.

758 Monograph of Venofer 2006, NDA 21-135/S-017, American regent, inc. shirley, NY 11967.

759 Muller EK, Grafe C, Wiekhorst F, Bergemann, Weidner A, Dutz S, Clement JH. Magnetic

760 Nanoparticles Interact and Pass an In Vitro Co-Culture Blood-Placenta Barrier Model. Nanomaterials

761 2018, 8: 108 (doi:10.3390/nano8020108).

762 Ndong C, Toraya-Brown S, KekaloK, Baker I, Gerngross TU, Fiering SN, Griswold KE. Antibody-

763 mediated targeting of iron oxide nanoparticles to the folate receptor alpha increases tumor cell

764 association in vitro and in vivo. International Journal of Nanomedicine 2015, 10: 2595-2617.

765 Ni D, Ferreira CA, Barnhart TE, Quach V, Yu B, Jiang, D, Wei W, Liu H, Engle JW, Hu P, Cai W.

766 Magnetic Targeting of Nanotheranostics Enhances Cerenkov Radiation-Induced Photodynamic

767 Therapy. J. Am. Chem. Soc. 2018, 140: 14971-14979.

768 Lin MM, Kim HH, Kim H, Muhammed M, Kim DK. Iron oxide-based nanomagnets in nanomedicine:

769 fabrication and applications. Nano Reviews 2010, 1: 4883 (DOI: 10.3402/nano.v1i0.4883).

770 Martínez-Mera I, Espinosa-Pesqueira ME, Perez-Hernadez R, Arenas-Alatorre J. Synthesis of magnetite

771 (Fe3O4) nanoparticles without surfactants at room temperature. Materials Letters 2007, 61: 4447-4451.

772 Obaidat IM, Issa B, Haik Y. Magnetic properties of Magnetic Nanoparticles for efficient Hyperthermia.

773 Nanomaterials 2015, 5: 68-89.

774 Ohno K, Mori C, Akashi T, Yoshida S, Tago Y, Tsujii Y, Tabata Y. Fabrication of Contrast Agents for

775 Magnetic Resonance Imaging from Polymer-Brush-Afforded Iron Oxide Magnetic Nanoparticles

776 Prepared by Surface-Initiated Living Radical Polymerization. Biomacromolecules 2013, 14: $777 \quad 3453-3462$.

778 Osborne EA, Atkins TM, Gilbert DA, Kauzlarich SM, Liu K, Louie AY. Rapid Microwave-Assisted 779 Synthesis of Dextran-Coated Iron Oxide Nanoparticles for Magnetic Resonance Imaging. $780 \quad$ Nanotechnology 2012, 23: 215602. 
781 Osuna J, Caro D, Amiens C, Chaudret B. Synthesis, Characterization, and Magnetic Properties of

782 Cobalt Nanoparticles from an Organometallic Precursor. J. Phys. Chem. 1996, 100: 14571-14574.

783 Parat A, Kryza D, Degoul F, Taleb J, Viallard C, Janier M, Garofalo A, Bonazza P, Heinrich-Balard L, 784 Cohen R, Miot-Noirault E, Chezal J-M, Billoteycg C, Felder-Flesch D. Radiolabeled dendritic probes as 785 tools for high in vivo tumor targeting: application to melanoma. J. Mat. Chem. B. 2015, 3: 2560-1571.

786 Park JH, Maltzahn G, Zhang L, Schwartz M, Ruoslati E, Bhatia SN, Sailor MJ. Magnetic Iron Oxide 787 Nanoworms for Tumor Targeting and Imaging. Adv Mater. 2008, 20: 1630-1635.

788 Park J, Cho W, Park HJ, Cha KH, Ha DC, Choi YW, Lee HY, Cho SH, Hwang SJ. Biodistribution of 789 newly synthesized PHEA-based polymer-coated SPION in Sprague Dawley rats as magnetic resonance 790 contrast agent. International Journal of Nanomedicine 2013, 8: 4077-4089.

791 Peng X-H, Qian X, Mao H, Wang AY, Chan Z, Nie S, Shin DM. Targeted magnetic iron oxide 792 nanoparticles for tumor imaging and therapy. International Journal of Nanomedicine 2008, 3: 311793321.

794 Périgo EA, Hemery G, Sandre O, Ortega D, Garaio E, Plazaola F, Teran FJ. Fundamentals and advances 795 in magnetic hyperthermia. Appl. Phys. Rev. 2015, 2: 041302.

796 Pham BTT, Colvin EK, Pham NTH, Kim BJ, Fuller ES, Moon EA, Barbey R, Yuen S, Rickman BH, 797 Bryce NS, Bickley S, Tanudji M, Jones SK, Howell VM, Hawkett BS. Biodistribution and Clearance of 798 Stable Superparamagnetic Maghemite Iron Oxide Nanoparticles in Mice Following Intraperitoneal 799 Administration. Int. J. Mol. Sci. 2018, 19: 205 (doi:10.3390/ijms19010205).

800 Phu ND, Ngo DT, Hoang LH, Luong N. H. Crystallization process and magnetic properties of 801 amorphous iron oxide nanoparticles. Journal of Physics D: Applied Physics. 2011, 44: 345002.

802 Prabu P, Vedakumari WS, Sastry TP. Time-dependent biodistribution, clearance and biocompatibility of 803 magnetic fibrin nanoparticles: an in vivo study. Nanoscale 2015, 7: 9676-9685.

804 Qian X, Han X, Chen Y. Insights into the unique functionality of inorganic micro/nanoparticles for 805 versatile ultrasound theranostics. Biomaterials 2017, 142: 13-30. 
806 Quan Q, Xie J, Gao H, Yang M, Zhang F, Liu G, Lin X, Wang, A, Eden HS, Lee S, Zhang G, Chen X.

807 HSA Coated Iron Oxide Nanoparticles as Drug Delivery Vehicles for Cancer Therapy. Mol.

808 Pharmaceutics 2011, 8: 1669-1676.

809 Ramimoghadam D, Bagheri S, Hamid SBA. Progress in electrochemical synthesis of magnetic iron

810 oxide nanoparticles. Journal of Magnetism and Magnetic Materials 2014, 368: 207-229.

811 Rao L, Bu LL, Xu JH, Cai B, Yu GT, Yu X, He Z, Huang Q, Li A, Guo SS, Zhang WF, Liu W, Sun ZJ,

812 Wang H, Wang TH, Zhao XZ. Red Blood Cell Membrane as a Biomimetic Nanocoating for Prolonged

813 Circulation Time and Reduced Accelerated Blood Clearance. Small 2015, 11: 6225-6236.

814 Reddy LH, Sharma RK, Chuttani K, Mishra AK, Murthy RSR. Influence of administration route on

815 tumor uptake and biodistribution of etoposide loaded solid lipid nanoparticles in Dalton's lymphoma

816 tumor bearing mice. Journal of Controlled Release 2005, 105: 185-198.

817 Remya NS, Syama S, Sabareeswaran A, Mohanan PV. Toxicity, toxicokinetics and biodistribution of

818 dextran stabilized Iron oxide Nanoparticles for biomedical applications. International Journal of

819 Pharmaceutics 2016, 511: 586-598.

820 Ruiz A, Hernandez Y, Cabal C, Gonzalez E, Veintemillas-Verdaguer S, Martınezc E, Morales MP.

821 Biodistribution and pharmacokinetics of uniform magnetite nanoparticles chemically modified with

822 polyethylene glycol. Nanoscale 2013, 5: 11400-11408.

823 Ruiz A, Gutiérrez L, Cáceres-Vélez PR, Santos D, Chaves SB, Fascineli ML, Garcia MP, Azevedoc

824 RB, Morales MP. Biotransformation of magnetic nanoparticles as a function of coating in a rat model.

$825 \quad$ Nanoscale 2015, 7: 16321-16329.

826 Sakulkhua U, Mahmoudib M, Maurizia L, Coullereza G, Hofmann-Amtenbrink M, Rezaeee F,

827 Motazacker M, Vriese M, Hofmanna H. Significance of surface charge and shell material of

828 Superparamagnetic Iron Oxide Nanoparticles (SPIONs) based core/shell nanoparticles on the

829 composition of the protein corona. Biomater. Sci. 2015, 3: 265-278. 
830 Sahoo Y, Goodarzi A, Swihart MT, Ohulchanskyy TY, Kaur N, Furlani EP, Prasad P. Aqueous

831 Ferrofluid of Magnetite Nanoparticles: Fluorescence Labeling and Magnetophoretic Control. J. Phys.

$832 \quad$ Chem. B 2005, 109: 3879-3885.

833 Sakulkhu U, Mahmoudi M, Maurizi L, Salaklang J, Hofmann H. Protein Corona Composition of

834 Superparamagnetic Iron Oxide Nanoparticles with Various Physico-Chemical Properties and Coatings.

835 Scientific reports, 4: 5020 (doi: 10.1038/srep05020).

836 Salazar-Alvarez G, Muhammed M, Zagorodni AA. Novel flow injection synthesis of iron oxide 837 nanoparticles with narrow size distribution, Chemical Engineering Science 2006, 61: 4625-4633.

838 Salimi M, Sarkar S, Fathi S, Alizadeh AM, Saber R, Moradi F, Delavari H. Biodistribution, 839 pharmacokinetics, and toxicity of dendrimer-coated iron oxide nanoparticles in BAL B/c mice. $840 \quad$ International Journal of Nanomedicine 2018, 13: 1483-1493.

841 Santoyo Salazar J, Perez L, Abril O, Phuoc LT, Ihiawakrim D, Vazquez M, Greneche JM, Begin-Colin

842 S, Pourroy G. Magnetic Iron Oxide Nanoparticles in 10-40 nm Range: Composition in Terms of 843 Magnetite/Maghemite Ratio and Effect on the Magnetic Properties. Chem. Mater. 2011, 23: $1379-1386$.

844 Santra S, Kaittanis C, Perez JM. Cytochrome c encapsulating theranostic nanoparticles: A novel 845 bifunctional system for targeted delivery of therapeutic membrane impermeable proteins to tumors and 846 imaging of cancer therapy. Mol. Pharmaceutics 2010, 7: 1209-1222.

847 Schleich N, Po C, Jacobs D, Ucakar B, Gallez B, Danhier F, Préat V. Comparison of active, passive and 848 magnetic targeting to tumors of multifunctional paclitaxel/SPIO-loaded nanoparticles for tumor imaging 849 and therapy. Journal of Controlled Release 2014, 194: 82-91.

850 Shanehsazzadeh, Oghabian MA, Daha FJ, Amanlou M, Allen BJ. Biodistribution of ultra small 851 superparamagnetic iron oxide nanoparticles in BALB mice. J Radioanal Nucl Chem 2013, 295:15178521523.

853 Shen CC, Wang CC, Liao MH, Jan TR. A single exposure to iron oxide nanoparticles attenuates 854 antigen-specific antibody production and T-cell reactivity in ovalbumin-sensitized BALB/c mice. 855 International Journal of Nanomedicine 2011, 6: 1229-1235. 
856 Simberg D, Park JH, Karmali PD, Zhang WM, Merkulov S, McCrae K, Bhatia SN, Sailor M, Ruoslahti

857 E. Differential proteomics analysis of the surface heterogeneity of dextran iron oxide nanoparticles and

858 the implications for their in vivo clearance. Biomaterials 2009, 30: 3926-3933.

859 Singh N, Jenkins GJS, Asadi R, Doak SH. Potential toxicity of superparamagnetic iron oxide 860 nanoparticles (SPION). Nano Reviews 2010, 1: 5358 (DOI: 10.3402/nano.v1i0.5358).

861 Soenen SJH, Nuytten N, De Meyer SF, De Smedt SC, De Cuyper M. High Intracellular Iron Oxide 862 Nanoparticle Concentrations Affect Cellular Cytoskeleton and Focal Adhesion Kinase-Mediated 863 Signaling. Small 2010, 6: 832-842.

864 Sonmez E, Aydin E, Turkez H, Özbek E, Togar B, Meral K, Çetin D, Cacciatore I, Di Stefano A. 865 Cytotoxicity and genotoxicity of iron oxide nanoparticles: an in vitro biosafety study. Arch. Biol. Sci. $8662016,68: 41-50$.

867 Stepien G, Moros M, Pérez-Hernández M, Monge M, Gutiérrez L, Fratila RM, De las Heras M, Guillén 868 SM, Lanzarote JJP, Solans C, Pardo J, De la Fuente JM. Effect of Surface Chemistry and Associated 869 Protein Corona on the Long-Term Biodegradation of Iron Oxide Nanoparticles In Vivo. ACS Appl. 870 Mater. Interfaces 2018, 10: 4548-4560.

871 Strehl C, Schellmann S, Maurizi L, Hofmann-Amtenbrink M, Häupla T, Hofmann H, Buttgereit F, 872 Gabera T. Effects of PVA-coated nanoparticles on human T helper cell activity. Toxicology Letters $8732016,245: 52-58$.

874 Sun Y, Duan L, Guo Z, DuanMu Y, Ma M, Xu L, Zhang Y, Gu N. An improved way to prepare 875 superparamagnetic magnetite-silica core-shell nanoparticles for possible biological application. Journal 876 of Magnetism and Magnetic Materials 2005, 285: 65-70.

877 Sun J, Wang S, Zhao, D, Han Hun F, Weng L, Liu H. Cytotoxicity, permeability, and inflammation of 878 metal oxide nanoparticles in human cardiac microvascular endothelial cells. Cell Biol Toxicol 2011, 27: $879333-342$.

880 Sun T, Zhang YS, Pang B, Hyun DC, Yang M, Xia Y. Engineered Nanoparticles for Drug Delivery in 881 Cancer Therapy. Angew. Chem. Int. Ed. 2014, 53: 12320-12364. 
Sun Z, Worden M, Thliveris JA, Hombach-Klonisch S, Klonisch T, Van Lierop J, Hegmann T, Miller

883 DW. Biodistribution of negatively charged iron oxide nanoparticles (IONPs) in mice and enhanced 884 brain delivery using lysophosphatidic acid (LPA). Nanomedicine: Nanotechnology, Biology, and 885 Medicine 2016, 12: 1775-1784.

886 Thorek DLJ, Chen AK, Czupryna J, Tsourkas A. Superparamagnetic Iron Oxide Nanoparticle Probes 887 for Molecular Imaging. Annals of Biomedical Engineering 2006, 34: 23-38.

888 Tietze R, Lyer S, Durr S, Struffert T, Engelhorn T, Schwarz M, Eckert E, Göen T, Vasylyev S, Peukert 889 W, Wiekhorst F, Trahms L, Dörfler A, Alexiou C, Efficient drug-delivery using magnetic 890 nanoparticles-biodistribution and therapeutic effects in tumour bearing rabbits. Nanomedicine 2013, 9: $891961-971$.

892 Treuel L, Jiang X, Nienhaus GU. New views on cellular uptake and trafficking of manufactured 893 nanoparticles. J R Soc Interface 2013, 10: 20120939.

894 Utani K-I, Kohno Y, Okamoto A, Shimizu N. Emergence of Micronuclei and Their Effects on the Fate 895 of Cells under Replication Stress. Plos One 2010, 5: e10089.

896 Veiseh O, Gunn J, Zhang M. Design and fabrication of magnetic nanoparticles for targeted drug 897 delivery and imaging. Adv Drug Deliv Rev. 2010, 62: 284-304.

898 Veintemillas-Verdaguer S, Morales MP, Serna SJ. Continuous production of $\gamma$-Fe O ultrafine powders 899 by laser pyrolysis. Materials Letters 1998, 35: 227-231.

900 Veiseh O, Sun C, Fang C, Bhattarai N, Gunn J, Kievit F, Du K, Pullar B, Lee D, Ellenbogen RG, Olson 901 J, Zhang M. Specific targeting of brain tumors with an optical/magnetic resonance imaging nanoprobe 902 across the blood-brain barrier. Cancer Res. 2009, 69: 6200-6207.

903 Walter A, Billotey C, Garofalo A, Ulhaq-Bouillet C, Lefèvre C, Taleb J, Laurent S, Vander Elst L, 904 Muller RN, Lartigue L, Gazeau F, Felder-Flesch D, Begin-Colin S. Mastering the Shape and 905 Composition of Dendronized Iron Oxide Nanoparticles To Tailor Magnetic Resonance Imaging and 906 Hyperthermia. Chem. Mat. 2014, 26: 5252-5264. 
907 Wan J, Chen X, Wang Z, Yang X, Qian Y. A soft-template-assisted hydrothermal approach to single-

908 crystal $\mathrm{Fe}_{3} \mathrm{O}_{4}$ nanorods. Journal of Crystal Growth 2005, 276: 571-576.

909 Wang J, Chen Y, Chen B, Ding J, Xia G, Gao C, Cheng J, Jin N, Zhou Y, Li X, Tang M, Wang XM.

910 Pharmacokinetic parameters and tissue distribution of magnetic $\mathrm{Fe}_{3} \mathrm{O}_{4}$ nanoparticles in mice.

911 International Journal of Nanomedicine 2010, 5: 861-866.

912 Wang L, Huang J, Chen H, Wu H, Xu Y, Li Y, Yi H, Wang YA, Yang L, Mao H. Exerting Enhanced

913 Permeability and Retention Effect Driven Delivery by Ultrafine Iron Oxide Nanoparticles with T1-T2

914 Switchable Magnetic Resonance Imaging Contrast. ACS Nano 2017, 11: 4582-4592.

915 Wei H, Brunsa OT, Kaulb MG, Hansen EC, Barch M, Wisniowska A, Chen O, Chen O, Li N, Okada S,

916 Cordero JM, Heine M, Farrar CT, Montanaa DM, Adamb G, Ittrich H, Jasanoff A,, Nielsen P, Bawendi

917 MG. Exceedingly small iron oxide nanoparticles as positive MRI contrast agents. PNAS 2017, 114:

$918 \quad 2325-2330$.

919 Wu W, He Q, Jiang C. Magnetic Iron Oxide Nanoparticles: Synthesis and Surface Functionalization 920 Strategies. Nanoscale Res Lett 2008, 3:397-415.

$921 \mathrm{Wu}$ W, Wu Z, Yu T, Jiang C, Kim WS. Recent progress on magnetic iron oxide nanoparticles: 922 synthesis, surface functional strategies and biomedical applications. Sci. Technol. Adv. Mater. 2015, 923 16: 023501.

924 Xie Y, Liu, D, Cai, C, Chen X, Zhou Y, Wu L, Sun Y, Dai H, Kong X, Liu P. Size-dependent 925 cytotoxicity of $\mathrm{Fe}_{3} \mathrm{O}_{4}$ nanoparticles induced by biphasic regulation of oxidative stress in different human 926 hepatoma cells. International Journal of Nanomedicine 2016, 11: 3557-3570.

927 Xu C, Shi S, Feng L, Chen F, Graves SA, Ehlerding EB, Goel S, Sun H, England CG, Nickles RJ, Liu 928 Z, Wang T, Cai W. Long circulating reduced graphene oxide-iron oxide nanoparticles for efficient 929 tumor targeting and multimodality imaging. Nanoscale, 2016, 8: 12683-12692.

930 Wang YXJ, Xuan S, Port M, Idee JM. Recent Advances in Superparamagnetic Iron Oxide Nanoparticles 931 for Cellular Imaging and Targeted Therapy Research. Current Pharmaceutical Design 2013, 19: 65759326593. 
933 Wang H, Mua Q, Reviaa R, Wanga K, Tiand B, Lina G, Leec W, Hong Y-K, Zhanga M. Iron oxide-

934 carbon core-shell nanoparticles for dual-modal imaging-guided photothermal therapy. Journal of 935 Controlled Release 2018, 289: 70-78.

936 Wilhelm S, Tavares AJ, Dai Q, Ohta S, Audet J, Dvorak HF, Chan WCW. Analysis of nanoparticle

937 delivery to tumours. Nature Reviews Materials 2016, 1:1-12.

938 Yang L,Guo G, Niu XY, Liu J. Dendritic Cell-Based Immunotherapy Treatment for Glioblastoma 939 Multiforme. BioMed Research International 2015, article ID 717530.

940 Yang L, Kuang H, Zhang W, Aguilar ZP, Xiong Y, Lai W, Xu H, Wei H. Size dependent 941 biodistribution and toxicokinetics of iron oxide magnetic nanoparticles in mice. Nanoscale 2015, 7: $942 \quad 625-636$.

943 Yang X, Hong H, Grailer JJ, Rowland IJ, Javadi A, Hurley SA, Xiao Y, Yang Y, Zhang Y, Nickles RJ,

944 Cai W, Steeber DA, Gong S. cRGD-functionalized, DOX-conjugated, and ${ }^{64} \mathrm{Cu}-\mathrm{labeled}$ 945 superparamagnetic iron oxide nanoparticles for targeted anticancer drug delivery and PET/MR imaging. 946 Biomaterials 2011, 32: 4151-4160.

947 Yu J, Yin W, Zheng X, Tian G, Zhang X, Bao T, Dong X, Wang Z, Gu Z, Ma X, Zhao Y. Smart $948 \mathrm{MoS}_{2} / \mathrm{Fe}_{3} \mathrm{O}_{4}$ Nanotheranostic for Magnetically Targeted Photothermal Therapy Guided by Magnetic 949 Resonance/Photoacoustic Imaging. Theranostics 2015, 5: 931-945.

950 Zadnik PL, Molina CA, Sarabia-Estrada R, Groves ML, Wablbler M, Mihalic J, McCarthy EF, 951 Gokaslslan ZL, Ivkov R, Sciubbbba, DM. Characterization of intratumor magnetic nanoparticle 952 distribution and heating in a rat model of metastatic spine disease. J Neurosurg Spine 2014, 20:740953750.

954 Zhao Z, Zhou Z, Bao J, Wang Z, Hu J, Chi X, Ni K, Wang R, Chen X, Chen Z, Gao J. Octapod iron 955 oxide nanoparticles as high performance $\mathrm{T}_{2}$ contrast agents for magnetic resonance imaging. Nature 956 communications 2013, 4:2266 (DOI: 10.1038/ncomms3266). 
957 Zhang C, Liu H, Cui Y, Li X, Zhang Z, Zhang Y, Wang D. Molecular magnetic resonance imaging of 958 activated hepatic stellate cells with ultrasmall superparamagnetic iron oxide targeting integrin $\alpha v \beta_{3}$ for 959 staging liver fibrosis in rat model. International Journal of Nanomedicine 2016, 11: 1097-1108.

960 Zhen G, Muir BW, Moffat BA, Harbour P, Murray KS, Moubaraki B, Suzuki K, Madsen I, Agron-

961 Olshina N, Waddington L, Mulvaney L, Hartley PG. Comparative Study of the Magnetic Behavior of 962 Spherical and Cubic Superparamagnetic Iron Oxide Nanoparticles. J. Phys. Chem. C 2011, 115, 327963334.

964 Zhou J, Zhang J, Gao W. Enhanced and selective delivery of enzyme therapy to 9L-glioma tumor via 965 magnetic targeting of PEG-modified, $\beta$-glucosidase-conjugated iron oxide nanoparticles. International 966 Journal of Nanomedicine 2014, 9: 2905-2917.

967 Zhu X, Tian S, Cai Z. Toxicity Assessment of Iron Oxide Nanoparticles in Zebrafish (Danio rerio) Early 968 Life Stages. Plos One 2012, 7: e46286.

969 Zolata H, Davani FA, Afarideh H. Synthesis, characterization and theranostic evaluation of Indium-111 970 labeled multifunctional superparamagnetic iron oxide nanoparticles. Nuclear Medicine and Biology 971 2015, 42: 164-170. 
972 FIGURES:

973 Figure 1: A schematic picture representing two different types of applications of iron oxide

974 nanoparticles for treatments of iron anemia disease and cancer.

975 Figure 2: The different properties of iron oxide nanoparticle properties influencing their biodistribution.

\section{TABLE:}

977 Table 1: Commercialized or CE marked iron oxide nanoparticles for treatments of iron anemia disease 978 and glioblastoma.

979 Table 2: Biodistribution properties and pharmacodynamics parameters of various iron oxide 980 nanoparticles.

981 Table 3: Percentage of injected IONP ending up in tumor through the EPR effects when different 982 quantities of IONP are administered intravenously to mice or rats bearing different types of tumors.

983 Table 4: Percentage of injected IONP ending up in tumor through molecular targeting when different 984 quantities of IONP conjugated to various targeting agents are administered intravenously to mice 985 bearing different types of tumors.

986 Table 5: Percentage of injected IONP ending up in tumor through magnetic targeting targeting when 987 different quantities of IONP are administered intravenously to mice bearing different types of tumors 988 and the tumor is exposed to a magnetic field of various strengths. 
Two medical applications of iron oxide nanoparticles

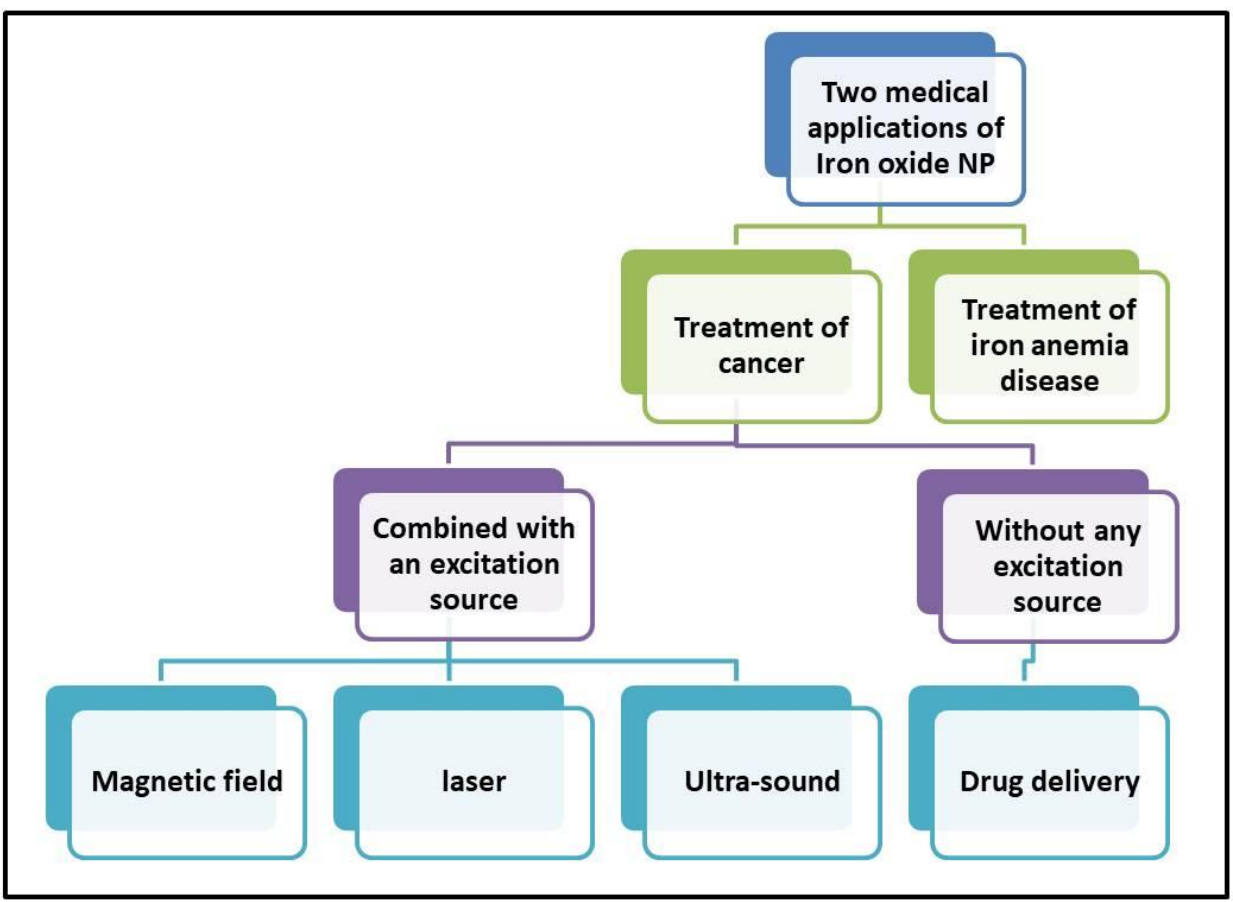

Figure 1 


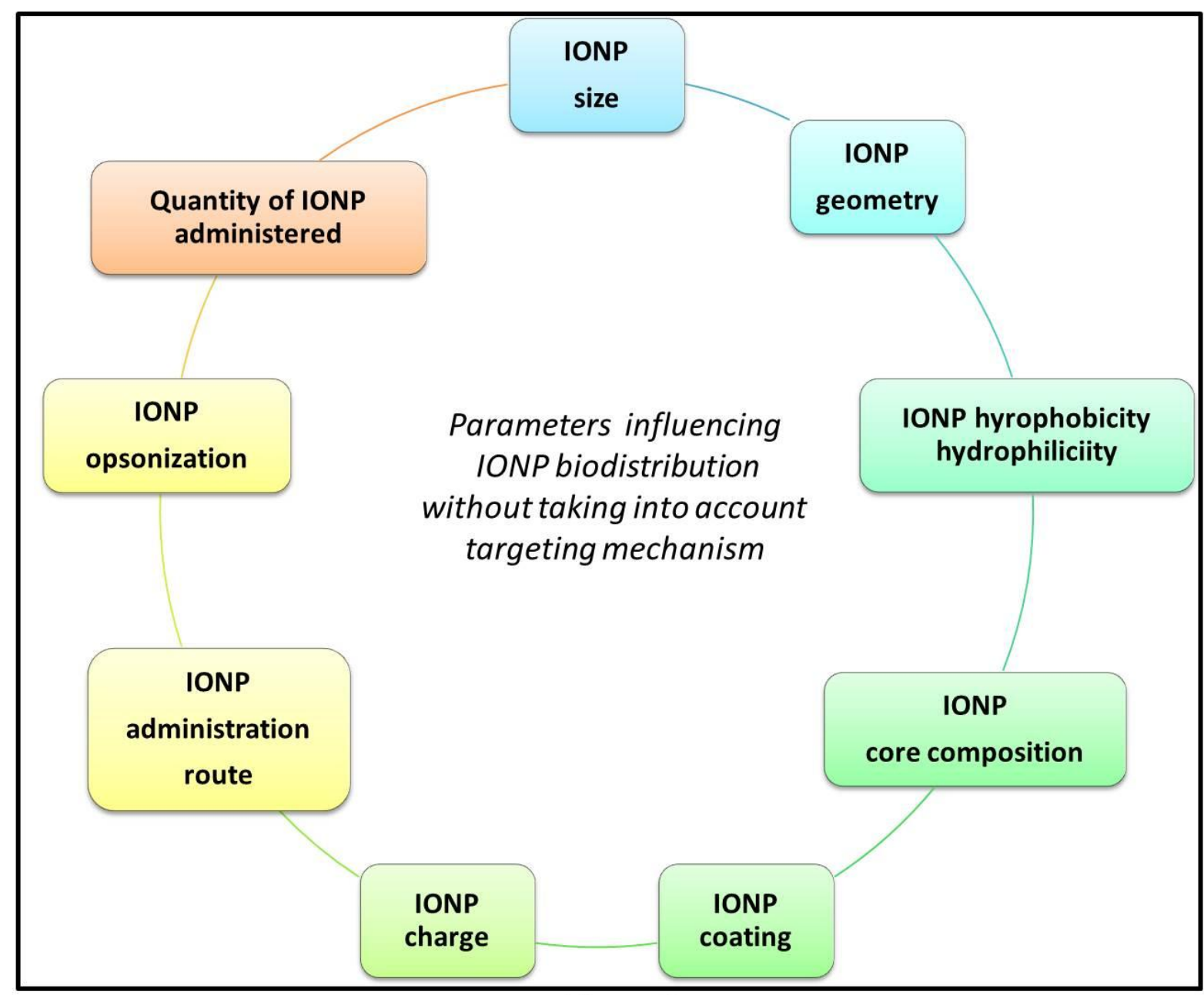

Figure 2 


\begin{tabular}{|c|c|c|c|}
\hline Product name & Product type & Status & Application \\
\hline $\begin{array}{l}\text { Feraheme, } \\
\text { Ferumoxytol, } \\
\text { Rienso }\end{array}$ & $\begin{array}{l}\text { FeOCHONa NP + polyglucose sorbitol } \\
\text { carboxymethyl ether coating }\end{array}$ & Commercialized & Treatment of IDA in patients with CKD \\
\hline Ferrisat & Iron + Dextran & Commercialized & Treatment of IDA \\
\hline Venofer & Iron + sucrose & Commercialized & Treatment of IDA in patients with CKD \\
\hline $\begin{array}{l}\text { DexFerrum, iron } \\
\text { dextran injection }\end{array}$ & Iron + dextran & Commercialized & Treatment of IDA in patients with CKD \\
\hline $\begin{array}{l}\text { Injectafter } \\
\text { Ferinject }\end{array}$ & Sodium ferric gluconate & Commercialized & Treatment of IDA in patients with CKD \\
\hline Nanotherm & amino-silane coated iron oxide nanoparticle & Commercialized & Magnetic hyperthermia treatment \\
\hline
\end{tabular}

Table 1 


\section{Biodistribution/pharmacodynamic parameters of $\mathrm{Fe}_{3} \mathrm{O}_{4} / \gamma \mathrm{Fe}_{2} \mathrm{O}_{3} \mathrm{NP}$}

\begin{tabular}{|c|c|c|c|c|c|c|c|c|c|c|}
\hline $\begin{array}{c}N P \\
\text { size }(\mathrm{nm}) \\
\text { name }\end{array}$ & Coating type & $\begin{array}{l}\text { Quant. } \\
\text { Admin. }\end{array}$ & $\begin{array}{l}\text { Admin. } \\
\text { Route }\end{array}$ & Animal & $\begin{array}{c}\text { Organs with large NP } \\
\text { accumulation }\end{array}$ & $\begin{array}{l}\text { Organs with low NP } \\
\text { accumulation }\end{array}$ & $\begin{array}{l}\text { Elimination } \\
\text { route }\end{array}$ & $\begin{array}{l}\text { Pharma. } \\
\text { paramet. }\end{array}$ & Remarks & $\begin{array}{c}\text { Ref } \\
\text { (first aut. } \\
\text { name/vear pub.) }\end{array}$ \\
\hline $\begin{array}{l}5,15,30 \\
\text { (TEM) } \\
13,30,50 \\
\text { (hydro) }\end{array}$ & PEG & $5 \mathrm{mg} / \mathrm{kg}$ & iv & Mice & Liver, spleen (24h) & Lung, kifney, brain (24h) & $\begin{array}{l}\text { Liver and spleen } \\
\text { Degraded products in blood }\end{array}$ & $\begin{array}{c}\mathrm{t}_{1 / 2}=200 \min \\
(5 \mathrm{~nm}) \\
\mathrm{t}_{1 / 2}=63 \mathrm{~min} \\
(30 \mathrm{~nm})\end{array}$ & $\begin{array}{c}\text { Decrease in half life with increasing } \\
\text { sizes }\end{array}$ & Gu2012 \\
\hline $12-15$ & DMSA & $\begin{array}{c}0.5-2 \\
\mathrm{mg} / \mathrm{kg}\end{array}$ & iv & pig & Liver, spleen & Lungs, & $\begin{array}{c}\text { Liver } \\
\text { (no accumulation in kidney) }\end{array}$ & $\mathrm{t}_{1 / 2}=15 \mathrm{~min}$ & $\begin{array}{l}\text { Decrease in blood pressure after NP } \\
\text { admin. }\end{array}$ & Edge2016 \\
\hline 11 & $\mathrm{OA}$ + pluronic & $\begin{array}{c}10 \\
\mathrm{mg} / \mathrm{kg}\end{array}$ & iv & Rats & Liver, spleen & Brain, heart, kidney, lung & $\begin{array}{l}18-22 \% \text { of NP through urine } \\
\text { and feces during } 7 \text { weeks }\end{array}$ & $\begin{array}{c}\text { Clearance }>3 \\
\text { weeks }\end{array}$ & None & $\begin{array}{l}\text { Jain } \\
2008\end{array}$ \\
\hline $\begin{array}{l}17-46 \\
\text { (hydro) }\end{array}$ & $\begin{array}{l}\text { PEG1500- } \\
\text { PEG800 }\end{array}$ & $\begin{array}{c}5 \\
\mathrm{mg} / \mathrm{kg}\end{array}$ & iv & mice & $\begin{array}{c}\text { Liver, kidney } \\
\text { (0-50 h. after amin.) }\end{array}$ & $\begin{array}{l}\text { Bladder, muscle } \\
\quad(0-50 \mathrm{~h})\end{array}$ & $\begin{array}{l}\text { Through Liver } \\
\text { Renal clerance }\end{array}$ & NA & $\begin{array}{l}\text { Very different biodistribution profile } \\
\text { compared with Gd }\end{array}$ & $\begin{array}{l}\text { Leal } \\
2015\end{array}$ \\
\hline $\begin{array}{l}32-46 \\
\text { (hydro) }\end{array}$ & $\begin{array}{l}\text { PEG } \\
\text { Dextran }\end{array}$ & $\begin{array}{c}100 \\
\mathrm{mg} / \mathrm{kg}\end{array}$ & iv & mice & $\begin{array}{l}\text { Liver, spleen } \\
\text { (24 h. after inj) }\end{array}$ & NA & Spleen and/or liver & $\mathrm{t}_{1 / 2}<1 \mathrm{~h}$ & $\mathrm{NP}$ in blood during $24 \mathrm{~h}$. & $\begin{array}{l}\text { Mohamaddi } \\
2018\end{array}$ \\
\hline $10-25$ & PEG & $\begin{array}{c}90 \\
\mathrm{mg} / \mathrm{kg}\end{array}$ & ip & $\begin{array}{l}\text { Mice } \\
\text { (ovarian } \\
\text { tumor) }\end{array}$ & $\begin{array}{l}\text { Liver, spleen, omentum, } \\
\text { mesentery } \\
\text { (0-1 week) }\end{array}$ & $\begin{array}{l}\text { Bladder, brain, colon, } \\
\text { heart, left kidney, left } \\
\text { ovary, lungs, peritoneum, } \\
\text { stomach, uterus }\end{array}$ & $\begin{array}{l}\text { Excretion in feces ( } 1 \mathrm{~h}-1 \text { week) } \\
\text { Spleen and liver macrophages }\end{array}$ & NA & $\begin{array}{l}\text { More NP in tumor for larger SPION } \\
(1-24 \mathrm{~h} \text { after admin.) }\end{array}$ & $\begin{array}{l}\text { Pham } \\
2018\end{array}$ \\
\hline 25 & Dextran & $\begin{array}{c}300-2000 \\
\mathrm{mg} / \mathrm{kg}\end{array}$ & iv & Mice & Liver, Spleen & kidney & $\begin{array}{l}\text { lack of defined pathway for } \\
\text { excretion }\end{array}$ & NA & $\begin{array}{l}\text { Iron accumulation in liver, spleen, } \\
\text { kidney does not induce tox. }\end{array}$ & $\begin{array}{l}\text { Remya } \\
2016\end{array}$ \\
\hline 12 & PEG & $\begin{array}{l}2.5-5 \\
\mathrm{mg} / \mathrm{kg}\end{array}$ & iv & Rats & $\begin{array}{l}\text { Liver } \\
(3 \mathrm{~h})\end{array}$ & $\begin{array}{l}\text { Spleen, lung } \\
\quad(3 \mathrm{~h})\end{array}$ & $\begin{array}{l}\text { Liver assimilation of iron } \\
\text { Excretion from liver in } 200 \mathrm{~h} \text {. }\end{array}$ & $\mathrm{t}_{1 / 2}=20 \mathrm{~min}$ & NP excreted in the form of free iron. & $\begin{array}{l}\text { Ruiz } \\
2013\end{array}$ \\
\hline $\begin{array}{c}10 \\
\text { (TEM) }\end{array}$ & dendrimer & $\begin{array}{c}250 \\
\mathrm{mg} / \mathrm{kg}\end{array}$ & ip & $\begin{array}{l}\text { Mice } \\
\text { (tumor) }\end{array}$ & $\begin{array}{l}\text { Liver, lung, heart, } \\
\text { kidney, tumor, heart } \\
(4-24 \mathrm{~h})\end{array}$ & NA & $\begin{array}{l}\text { Excretion through kidney and } \\
\text { absorption in lungs }\end{array}$ & $t_{1 / 2}<24 h$ & Unusual mode of excretion & Salimi2018 \\
\hline $\begin{array}{c}41 \\
\text { (hydro) }\end{array}$ & dextran & $\begin{array}{c}50 \\
\mathrm{mg} / \mathrm{kg}\end{array}$ & iv & Mice & $\begin{array}{l}\text { Liver }(<24 \mathrm{~h}) \\
\text { Heart }(<5 \mathrm{~min}) \\
\text { Lung }(<60 \mathrm{~min})\end{array}$ & $\begin{array}{c}\text { Kidney, adrenal, } \\
\text { pancreas, tail, carcass }\end{array}$ & $\begin{array}{l}\text { Feces excretion negligible. } \\
\text { NP accumulate in liver + spleen }\end{array}$ & $\mathrm{t}_{1 / 2}<5 \mathrm{~min}$ & $\begin{array}{c}\text { Gradual increase of NP } \\
\text { accumulation in spleen (peak at } 60 \\
\text { min) }\end{array}$ & $\begin{array}{c}\text { Shanehsazzadeh } \\
2013\end{array}$ \\
\hline $\begin{array}{c}29 \\
\text { (hydro) }\end{array}$ & $\begin{array}{c}\text { EDT } \\
\text { Ethylenediami- } \\
\text { netriacetate }\end{array}$ & & iv & Mice & Liver (<30 min) & Spleen, kidney (<30 min) & $\begin{array}{l}\text { Essentially liver (possibly a } \\
\text { little bit through kidney) }\end{array}$ & $\mathrm{t}_{1 / 2}=6 \mathrm{~min}$ & $\begin{array}{l}\text { Can cross the BBB due to the } \\
\text { coating LPA }\end{array}$ & Sun2016 \\
\hline $\begin{array}{c}20 \\
\text { (TEM) }\end{array}$ & None & $\begin{array}{c}600 \quad \text { । } \\
\mathrm{mg} / \mathrm{kg}\end{array}$ & Intra-gastric & Mice & Liver, Spleen (> 10 days) & $\begin{array}{l}\text { Heart, lungs, kidneys, } \\
\text { brain, stomac, small } \\
\text { intestine (>10 days) }\end{array}$ & Renal excretion modest & $\mathrm{t}_{1 / 2}>10$ days & IONP can cross the BBB & Wang2011 \\
\hline $\begin{array}{l}2.5-7 \\
\text { (TEM) }\end{array}$ & $\begin{array}{l}\text { ZDS } \\
\text { Zwitterionic } \\
\text { dopmanie } \\
\text { sulfonate }\end{array}$ & $\begin{array}{c}12 \\
\mathrm{mg} / \mathrm{kg}\end{array}$ & iv & Mice & Liver, carcass & $\begin{array}{l}\text { GIT, Kidney, Spleen, lung, } \\
\text { heart, tail ( } 24 \mathrm{~h})\end{array}$ & $\begin{array}{l}\text { After } 24 \mathrm{~h} \text {, majority of iron } \\
\text { from NP in urines }\end{array}$ & NA & $\begin{array}{c}\text { Renal clearance due to small size of } \\
\text { IONP }\end{array}$ & Wei2017 \\
\hline 20 (TEM) & NA & $\begin{array}{c}600 \quad \text { । } \\
\mathrm{mg} / \mathrm{Kg}\end{array}$ & Intra-gastric & Mice & Liver, spleen & $\begin{array}{l}\text { Heat, lungs, kidney, brain, } \\
\text { stomach, small intestine }\end{array}$ & Modest renal excretion & NA & Presence of IONP in all organs & Wang2010 \\
\hline $10,20,30,40$ & carboxyl & $20 \mathrm{mg} / \mathrm{Kg}$ & iv & Mice & $\begin{array}{l}10 \mathrm{~nm} \text { IONP: liver } \\
40 \mathrm{~nm} \text { IONP: Spleen }\end{array}$ & $\begin{array}{l}\text { stomach, } \\
\text { intestine, and uterus }\end{array}$ & $\begin{array}{l}\text { All IONP in Feces } \\
\text { Small IONP }(10 \mathrm{~nm}) \text { in urine }\end{array}$ & NA & $\begin{array}{l}\text { Biodistribution and elimination } \\
\text { depends on size of IONP }\end{array}$ & Yang2015 \\
\hline
\end{tabular}

Table 2-1 


\begin{tabular}{|c|c|c|c|c|c|c|c|c|c|c|}
\hline $\begin{array}{c}\text { IONP } \\
\text { size }(\mathrm{nm}) \\
\text { name }\end{array}$ & \begin{tabular}{|c|} 
Not Fe203 \\
Coating / drug
\end{tabular} & $\begin{array}{l}\text { Quant. } \\
\text { Admin. }\end{array}$ & $\begin{array}{l}\text { Admin. } \\
\text { Route }\end{array}$ & Animal & $\begin{array}{l}\text { Organ with larger NP } \\
\text { accumulation }\end{array}$ & $\begin{array}{l}\text { Organs with lower NP } \\
\text { accumulation }\end{array}$ & $\begin{array}{l}\text { Elimination } \\
\text { route }\end{array}$ & $\begin{array}{l}\text { Pharma. } \\
\text { paramet. }\end{array}$ & Remarks & $\begin{array}{c}\text { Ref } \\
\text { (first aut. } \\
\text { ame/year pub.) }\end{array}$ \\
\hline $\begin{array}{c}20 \\
\text { (TEM) }\end{array}$ & PEG & $\begin{array}{c}10 \\
\mathrm{mg} / \mathrm{kg}\end{array}$ & iv & Mice & Liver, spleen $(24 \mathrm{~h}, 72 \mathrm{~h})$ & Kidney $(24 h, 72 h)$ & NA & NA & NA & $\begin{array}{l}\text { Arami } \\
2015\end{array}$ \\
\hline NA & $\begin{array}{l}\text { Chitosan + } \\
\text { Cholorotoxin } \\
\text { (targeting) }\end{array}$ & $\begin{array}{c}10 \\
\mathrm{mg} / \mathrm{kg}\end{array}$ & iv & Mice & $\begin{array}{l}\text { Liver, spleen, kidney (0- } \\
48 \mathrm{~h}) \\
\text { No diff. with/without } \\
\text { targeting }\end{array}$ & $\begin{array}{l}\text { Colon, brain, heart, lung, } \\
\text { pancreas, muscle, small } \\
\text { intestine, gonad, bone } \\
\text { marrow (0-48h) } \\
\text { No diff with/without } \\
\text { targeting }\end{array}$ & Kidney and liver & $\begin{array}{c}\mathrm{t}_{1 / 2}=8 \mathrm{~h} \text { (with } \\
\text { targeting) } \\
\mathrm{t}_{1 / 2}=7 \mathrm{~h} \text { (without } \\
\text { targeting) }\end{array}$ & $\begin{array}{l}\text { Longer circulation with targeting } \\
\text { molecule that prevents elimination. }\end{array}$ & $\begin{array}{l}\text { Lee } \\
2010\end{array}$ \\
\hline $\begin{array}{c}5 \\
\text { (TEM) } \\
10-20 \\
\text { (hydro) }\end{array}$ & $\begin{array}{c}\text { PEG } \\
\text { RGD-modified }\end{array}$ & $5 \mathrm{mg} / \mathrm{Kg}$ & iv & $\begin{array}{l}\text { Mice bearing } \\
\text { HepG2 tumor }\end{array}$ & $\begin{array}{l}\text { Liver, spleen } \\
\text { (not a big difference } \\
\text { between blank, PEG, } \\
\text { RGD-modified) }\end{array}$ & $\begin{array}{l}\text { Heart, lung, kidney, } \\
\text { tumor }\end{array}$ & liver & $t_{1 / 2}=92 \min (R G D)$ & $\begin{array}{l}\text { For heart, liver, spleen, lung, kidney): No } \\
\text { difference in biidostribution between } \\
\text { blank, PEG-IONP or RGD-IONP } \\
\text { For tumor: No difference between } \\
\text { IONP-RGD and IONP-PEG }\end{array}$ & Jia2016 \\
\hline $\begin{array}{c}120 \\
\text { (hydro) }\end{array}$ & $\begin{array}{l}\text { DOXO + RGD } \\
\text { (targeted) } \\
\text { DOXO (non- } \\
\text { targeted) }\end{array}$ & $0.5 \mathrm{mg} / \mathrm{Kg}$ & iv & $\begin{array}{l}\text { Mice bearing } \\
\text { CNS-1 GBM }\end{array}$ & $\begin{array}{r}\text { Non-targeted organ: dist } \\
\text { heart, bra }\end{array}$ & $\begin{array}{l}\text { stribution in liver, spleen, } \\
\text { ain, kidney }\end{array}$ & Organs of the RES & NA & $\begin{array}{l}\text { Non-targeted IONP: } 2 \% \text { in tumor } \\
\text { Targeted IONP: } 4.5 \% \text { in tumor }\end{array}$ & Karathanasis2016 \\
\hline $\begin{array}{c}8-10 \\
\text { (TEM) } \\
66 \\
\text { (hydro) }\end{array}$ & PHEA & $1 \mathrm{mg} / \mathrm{Kg}$ & iv & Rats & liver & $\begin{array}{l}\text { Spleen, lung, kidney, } \\
\text { small intestine }\end{array}$ & $\begin{array}{l}\text { Liver (faces excretion) } \\
\text { Kidney (urine excretion) }\end{array}$ & $\begin{aligned} \mathrm{t}_{1 / 2} & =15-24 \mathrm{~min} \\
& \text { (blood). } \\
\mathrm{t}_{1 / 2} & =6-20 \text { days } \\
& \text { (liver) }\end{aligned}$ & $\begin{array}{l}\text { IONP laneled with } 59 \mathrm{Fe} \text { eliminated by } \\
\text { kidney and faces } \\
\text { IONP labeled with } 14 \mathrm{C} \text { eliminated by } \\
\text { faces }\end{array}$ & Park2013 \\
\hline $\begin{array}{l}\text { Resovist } \\
65 \text { (hydro) }\end{array}$ & $\begin{array}{l}\text { Dextran } \pm \\
\text { fucoidan }\end{array}$ & $2 \mathrm{mg} / \mathrm{kg}$ & iv & $\begin{array}{l}\text { Mice bearing } \\
\text { GL261 tumor }\end{array}$ & Liver, blood, spleen & Heart, kidney & $\begin{array}{l}\text { Liver + kidney ( } w \\
\quad \text { fucoidan) } \\
\text { Liver (wo fucoidan) }\end{array}$ & $\begin{array}{l}\mathrm{t}_{1 / 2}=37 \text { min } \mathrm{w} / \mathrm{o} \\
\quad \text { fucoidan } \\
\mathrm{t}_{1 / 2}=150 \min \mathrm{w} \\
\quad \text { fucoidan }\end{array}$ & $\begin{array}{l}\text { With fucoidan, two times more IONP in } \\
\text { the tumor }\end{array}$ & Abdollah2018 \\
\hline 18 & Rituximab & $6.4 \mathrm{mg} / \mathrm{kg}$ & iv & $\begin{array}{l}\text { Mice bearing } \\
\text { CD- } 20 \text { tumor }\end{array}$ & $\begin{array}{l}\text { Liver, spleen, kidney, } \\
\text { blood, tumor, stomach } \\
\text { (time dependent) } \\
\% \text { tumor }=9 \% \mathrm{ID} / \mathrm{g} .\end{array}$ & Intestine, muscle & NA & NA & $\begin{array}{c}\text { Compartive kinetics for different } \\
\text { organs: } \\
\text { IONP in Lung, kidney, spleen, liver, } \\
\text { intestine, stomac: } \pi \text { during } 5-15 \mathrm{~h} \text { then } \\
y \\
\text { IONP in blood, heart : gradual decrease } \\
\text { IONP in tumor: gradual increase }\end{array}$ & Azadkbakht2018 \\
\hline $\begin{array}{c}10 \text { (TEM) } \\
47 \text { (hydro) }\end{array}$ & Polyacrylic acid & $\begin{array}{c}8,20,50 \\
\mathrm{mg} / \mathrm{kg}\end{array}$ & iv & Mice & $\begin{array}{l}\text { Liver, spleen (dose } \\
\text { dependant) }\end{array}$ & Lung, heart, tail & NA & NA & $\begin{array}{l}\text { Accumulation in liver and spleen } \\
\text { increases with increasing quantity of } \\
\text { IONP administered }\end{array}$ & Couto2016 \\
\hline 20 & $\begin{array}{l}\text { PEGMA (LMW } \\
=14000 \text { and } \\
\text { HMW }=130 \\
000)\end{array}$ & $50 \mathrm{mg} / \mathrm{Kg}$ & iv & Mice & $\begin{array}{l}\text { LMW: Spleen, liver, lung } \\
\text { HMW: heart, lung, } \\
\text { thymus, liver, spleen, } \\
\text { kidney, tumor }\end{array}$ & $\begin{array}{l}\text { LMW: Heart, thymus, } \\
\text { kidney, tumor } \\
\text { HMW: none }\end{array}$ & NA & $\begin{aligned} \mathrm{t}_{1 / 2} & =24 \mathrm{~h}(\mathrm{HMW}) \\
\mathrm{t}_{1 / 2} & <2 \mathrm{~h}(\mathrm{LMW})\end{aligned}$ & $\begin{array}{l}\text { Much longer circulation time and higher } \\
\text { accumulation ifn tumor for HMW than } \\
\text { LMW }\end{array}$ & Ohno2013 \\
\hline 26 (hydro) & fibrin & $5 \mathrm{mg} / \mathrm{Kg}$ & iv & Mice & Liver & $\begin{array}{c}\text { Spleen, lung, kidney, } \\
\text { heart }\end{array}$ & Urine and feces & $\mathrm{t}_{1 / 2}=12$ hours & $\begin{array}{l}\text { Accumulation of IONP in liver and } \\
\text { progressive departure of IONP from } \\
\text { liver between } 6 \mathrm{~h} \text { and } 28 \mathrm{~d}\end{array}$ & Prabu2015 \\
\hline 41 (hydro) & $\begin{array}{c}\text { Dextran + } \\
\text { DOTA }\end{array}$ & $4 \mathrm{mg} / \mathrm{Kg}$ & iv & $\begin{array}{l}\text { Mice with breast } \\
\text { tumor }\end{array}$ & Blood, liver, tumor & $\begin{array}{l}\text { Kidney, stomach, } \\
\text { intestine, colon, heart, } \\
\text { lung, bone }\end{array}$ & NA & NA & $\begin{array}{c}\text { Between } 4 \mathrm{~h} \text { and } 24 \mathrm{hpost} \text { inject., IONP } \\
\text { leave blood and remain in liver and } \\
\text { tumor } \\
\% \text { ID in tumor }=0.25 \%\end{array}$ & Rasaneh2015 \\
\hline 12 & Glucose or PEG & $6 \mathrm{mg} / \mathrm{kg}$ & iv & Mice & Liver, spleen & NA & NA & NA & $\begin{array}{l}\text { Accelerated degradation and clerance } \\
\text { with PEG compared with glucose }\end{array}$ & Stepien2018 \\
\hline
\end{tabular}

\section{Table 2-2}




\begin{tabular}{|c|c|c|c|c|c|c|c|}
\hline IONP type / size & $\begin{array}{l}\text { Admin. } \\
\text { Route }\end{array}$ & $\begin{array}{l}\text { Quantity } \\
\text { admin. }\end{array}$ & $\begin{array}{l}\text { Tumor volume } \\
\text { Tumor weight }\end{array}$ & Tumor type & $\begin{array}{c}\text { Percentage of injected dose } \\
\text { per gram of tumor }\end{array}$ & Percentage of IONP in tumor (\% ID) & Ref. \\
\hline $\begin{array}{l}\text { SPION encapsulated } \\
\text { in nanocapsule }\end{array}$ & iv & $\begin{array}{l}2 \mathrm{mg} \\
\text { (mice) }\end{array}$ & $\begin{array}{c}100 \mathrm{~mm}^{3} \\
0.2 \mathrm{~g}\end{array}$ & $\begin{array}{l}\text { CT-26 colon } \\
\text { tumor }\end{array}$ & $2 \%$ & $0.2 \%$ & Al-Jamal2016 \\
\hline $\begin{array}{l}\text { G100 starch coated IONP } \\
\text { (Chemicell) }\end{array}$ & iv & $\begin{array}{l}1.7 \mathrm{mg} \\
\text { (rats) }\end{array}$ & $\begin{array}{l}50-70 \mathrm{~mm}^{3} \\
\quad 0.1 \mathrm{~g}\end{array}$ & 9L glioma & $5.10^{-3} \%$ & $5.10^{-4} \%$ & Chertok2007 \\
\hline IONP of $30 \mathrm{~nm}$ & iv & $\begin{array}{l}2 \mathrm{mg} \\
\text { (mice) }\end{array}$ & $\begin{array}{l}100-200 \mathrm{~mm}^{3} \\
0.2 \mathrm{~g}\end{array}$ & $\begin{array}{l}\text { BT- } 474 \text { breast } \\
\text { cancer cells }\end{array}$ & $7 \%$ & $1.4 \%$ & Dong2015 \\
\hline IONP of $100 \mathrm{~nm}$ & iv & $\begin{array}{c}2 \mathrm{mg} \\
\text { (mice) }\end{array}$ & $\begin{array}{c}100-200 \mathrm{~mm}^{3} \\
0.2 \mathrm{~g}\end{array}$ & $\begin{array}{l}\text { BT- } 474 \text { breast } \\
\text { cancer cells }\end{array}$ & $0.75-1.25 \%$ & $0.15-0.25 \%$ & Dong2015 \\
\hline $\begin{array}{c}\text { SPIO }(6-10 \mathrm{~nm}) \\
\text { (Taiwan advanced Nanotech) }\end{array}$ & iv & $\begin{array}{c}300 \mu \mathrm{g} \\
\text { (rats) }\end{array}$ & $\begin{array}{c}20 \mathrm{~mm}^{3} \\
0.1 \mathrm{~g}\end{array}$ & C6 glioma & $1 \%$ & $0.1 \%$ & Fan2013 \\
\hline $\begin{array}{c}\text { SPION with } \\
\text { amino groups }(36 \mathrm{~nm})\end{array}$ & iv & $\begin{array}{l}4 \mathrm{mg} \\
\text { (rats) }\end{array}$ & $\begin{array}{c}23 \mathrm{~mm}^{3} \\
0.1 \mathrm{~g}\end{array}$ & C6 glioma & $0.1 \%$ & $0.01 \%$ & Fan2016 \\
\hline $\begin{array}{l}\text { SPION embedded } \\
\text { nanobubbles }\end{array}$ & iv & $\begin{array}{l}3 \mathrm{mg} \\
\text { (rats) }\end{array}$ & $\begin{array}{c}100 \mathrm{~mm}^{3} \\
0.2 \mathrm{~g}\end{array}$ & Glioma tumor & $3 \%$ & $0.6 \%$ & Huang2013 \\
\hline $\begin{array}{l}\text { SPION (10 nm) } \\
\text { in nanocapsule }\end{array}$ & iv & $\begin{array}{l}1.4 \mathrm{mg} \\
\text { (mice) }\end{array}$ & $\begin{array}{c}400-600 \mathrm{~mm}^{3} \\
0.5 \mathrm{~g}\end{array}$ & $\begin{array}{c}\text { CT26 } \\
4 \mathrm{~T} 1 \\
\text { LLC } \\
\text { B16F10 }\end{array}$ & $\begin{array}{c}2.5 \%(\mathrm{CT} 26) \\
2 \%(4 \mathrm{~T} 1) \\
1 \%(\mathrm{LLC}) \\
2 \%(\mathrm{~B} 16 \mathrm{~F} 10)\end{array}$ & $\begin{array}{c}1.25 \%(\mathrm{CT} 26) \\
1 \%(4 \mathrm{~T} 1) \\
0.5 \%(\mathrm{LLC}) \\
1 \%(\mathrm{BL} 6 \mathrm{~F} 10)\end{array}$ & Mei2016 \\
\hline SPION (ZnMnFeO) & iv & $\begin{array}{l}0.8 \mathrm{mg} \\
\text { (mice) }\end{array}$ & $\begin{array}{c}150 \mathrm{~mm}^{3} \\
0.2 \mathrm{~g}\end{array}$ & 4T1 tumor & $5 \%$ & $1 \%$ & $\mathrm{Ni} 2018$ \\
\hline $\begin{array}{c}\text { IONP }(240 \mathrm{~nm}) \\
\text { IONP + Paclitaxel }(240 \mathrm{~nm})\end{array}$ & iv & $\begin{array}{l}0.2-0.5 \mathrm{mg} \\
\text { (mice) }\end{array}$ & $\begin{array}{c}50-100 \mathrm{~mm}^{3} \\
0.1-0.2 \mathrm{~g}\end{array}$ & СТ26 & NA & $\begin{array}{c}0.1 \% \text { (SPION) } \\
0.1 \% \text { (SPION+ Paclitaxel) }\end{array}$ & Schleich2014 \\
\hline $\begin{array}{c}\text { SPION + PEG }(7 \mathrm{~nm}) \\
\text { SPION + two PEG }(7 \mathrm{~nm})\end{array}$ & iv & $\begin{array}{l}0.125 \mathrm{mg} \\
\text { (mice) }\end{array}$ & $\begin{array}{c}100 \mathrm{~mm}^{3} \\
0.2 \mathrm{~g}\end{array}$ & $4 \mathrm{~T} 1$ & $\begin{array}{c}8 \%(\text { IONP + PEG) } \\
15 \%(\text { IONP + } 2 \text { PEG) }\end{array}$ & $\begin{array}{l}1.6 \%(\text { IONP + PEG) } \\
3 \%(\text { IONP + } 2 \text { PEG) }\end{array}$ & Xu2016 \\
\hline $\begin{array}{c}\text { Starch coated D-MNP } \\
\text { (Chemicell) conjugated with PEG } \\
\text { and } \beta \text {-glucosidase }\end{array}$ & IV & $\begin{array}{l}0.24 \mathrm{mg} \\
\text { (mice) }\end{array}$ & $\begin{array}{c}300-400 \mathrm{~mm}^{3} \\
0.4 \mathrm{~g}\end{array}$ & 9L glioma & $1 \%$ & $0.4 \%$ & Zhou2014 \\
\hline $\begin{array}{c}\text { Starch coated D-MNP } \\
\text { (Chemicell) conjugated with } \beta \text { - } \\
\text { glucosidase }\end{array}$ & IV & $\begin{array}{l}0.24 \mathrm{mg} \\
\text { (mice) }\end{array}$ & $\begin{array}{c}300-400 \mathrm{~mm}^{3} \\
0.4 \mathrm{~g}\end{array}$ & 9L glioma & $0.5 \%$ & $0.2 \%$ & Zhou2014 \\
\hline $\begin{array}{l}\text { Starch coated D-MNP } \\
\text { (Chemicell) }\end{array}$ & iv & $\begin{array}{l}0.24 \mathrm{mg} \\
\text { (mice) }\end{array}$ & $\begin{array}{l}300-400 \mathrm{~mm}^{3} \\
0.4 \mathrm{~g}\end{array}$ & 9L glioma & $0.1 \%$ & $0.04 \%$ & Zhou2014 \\
\hline
\end{tabular}

Table 3

Molecular targeting of tumors with different types of iron oxyde nanoparticles

\begin{tabular}{|c|c|c|c|c|c|c|c|c|}
\hline $\begin{array}{l}\text { IONP type } \pm \text { targeting } \\
\text { agent (TA) }\end{array}$ & $\begin{array}{c}\text { Admin. } \\
\text { Route }\end{array}$ & $\begin{array}{l}\text { Quantity } \\
\text { admin. }\end{array}$ & $\begin{array}{l}\text { Molecular targeting } \\
\text { (MDT) }\end{array}$ & $\begin{array}{c}\text { Type of targeted } \\
\text { tumor }\end{array}$ & $\begin{array}{l}\text { Tumor } \\
\text { volume/ } \\
\text { Weight }\end{array}$ & $\begin{array}{l}\text { Percentage of injected } \\
\text { dose per gram of tumor } \\
\text { (\%ID/g of tumor) }\end{array}$ & $\begin{array}{c}\text { Percentage of IONP in } \\
\text { tumor (\% ID) }\end{array}$ & Ref. \\
\hline $\begin{array}{l}\text { SPION (BNF) + PSMA } \\
\text { antibody (with TA) }\end{array}$ & iv & $\begin{array}{l}0.25-4 \mathrm{mg} \\
\text { (mice) }\end{array}$ & $\begin{array}{l}\text { PSMA antibody } \\
\text { Targets PSMA }\end{array}$ & $\begin{array}{l}\text { PC3 prostate } \\
\text { tumor }\end{array}$ & $\begin{array}{c}140 \mathrm{~mm}^{3} \\
0.2 \mathrm{~g}\end{array}$ & $2.9 \%$ (with TA) & $0.6 \%$ (with TA) & Azad2015 \\
\hline $\begin{array}{l}\text { SPION (BNF) + anti-GD2 } \\
\text { antibody (with TA) }\end{array}$ & iv & $\begin{array}{l}0.073 \mathrm{mg} \\
\text { (mice) }\end{array}$ & $\begin{array}{l}\text { GD2 expressed on } \\
\text { CHLA-20 neuroblastoma }\end{array}$ & $\begin{array}{l}\text { CHLA-20 } \\
\text { neuroblastoma } \\
\text { Xenografts }\end{array}$ & NA & $\begin{array}{c}5.7 \% \text { (with TA) } \\
0 \% \text { (without TA) }\end{array}$ & NA & Baiu2015 \\
\hline SPION + Biotin (with TA) & iv & NA & $\begin{array}{c}\text { Targets avidin injected in } \\
\text { the tumor }\end{array}$ & NA & $\begin{array}{c}130 \mathrm{~mm}^{3} \\
0.2 \mathrm{~g}\end{array}$ & $0.6 \%$ (with TA) & $0.1 \%$ (with TA) & $\begin{array}{l}\text { Chauhan } \\
\text { 2013a }\end{array}$ \\
\hline SPION + folate (with TA) & iv & NA & $\begin{array}{l}\text { Targets folate receptors } \\
\text { of KB cancer cells }\end{array}$ & KB cells & $\begin{array}{c}1.6 \mathrm{~cm}^{3} \\
1.9 \mathrm{~g}\end{array}$ & $0.2-0.6 \%$ (with TA) & $0.38-1.14 \%$ (with TA) & $\begin{array}{l}\text { Chauhan } \\
\text { 2013b }\end{array}$ \\
\hline $\begin{array}{c}\text { IONP of } 30 \mathrm{~nm} \\
\text { (without TA) } \\
\text { IONP of } 30 \mathrm{~nm}+ \\
\text { Trastuzufab (with TA) }\end{array}$ & iv & $\begin{array}{l}2 \mathrm{mg} \\
\text { (mice) }\end{array}$ & $\begin{array}{l}\text { Trastuzufab antibody } \\
\text { binds to HER2 expressed } \\
\text { on tumor cells }\end{array}$ & $\begin{array}{l}\text { BT-474 breast } \\
\text { cancer cells }\end{array}$ & $\begin{array}{l}100-200 \mathrm{~mm}^{3} \\
0.2 \mathrm{~g}\end{array}$ & $\begin{array}{l}7 \% \text { (without TA) } \\
15 \% \text { (with TA) }\end{array}$ & $\begin{array}{c}\text { 1.4\% (without TA) } \\
\text { 3\% (with TA) }\end{array}$ & Dong 2015 \\
\hline $\begin{array}{c}\text { IONP of } 100 \mathrm{~nm} \\
\text { (without TA) } \\
\text { IONP of } 100 \mathrm{~nm}+ \\
\text { Trastuzufab (with TA) }\end{array}$ & iv & $\begin{array}{c}2 \mathrm{mg} \\
\text { (mice) }\end{array}$ & $\begin{array}{l}\text { Trastuzufab antibody } \\
\text { binds to HER2 expressed } \\
\text { on tumor cells }\end{array}$ & $\begin{array}{l}\text { BT-474 breast } \\
\text { cancer cells }\end{array}$ & $\begin{array}{l}100-200 \mathrm{~mm}^{3} \\
0.2 \mathrm{~g}\end{array}$ & $\begin{array}{c}0.75-1.25 \% \text { (without TA) } \\
0.75-1.25 \% \text { (with TA) }\end{array}$ & $\begin{array}{c}0.15-0.25 \% \text { (without TA) } \\
0.15-025 \% \text { (with TA) }\end{array}$ & Dong 2015 \\
\hline $\begin{array}{l}\text { IONP (without TA) } \\
\text { IONP + Ffab (with TA) } \\
\text { IONP + CMD + Ffab } \\
\text { (with TA + CMD) }\end{array}$ & ip & $\begin{array}{l}0.75 \mathrm{mg} \\
\text { (mice) }\end{array}$ & $\begin{array}{l}\text { Ffab binds to } \\
\text { recombinant FOLR } \alpha \\
\text { (rFOLR } \alpha)\end{array}$ & $\begin{array}{l}\text { KB cells (human } \\
\text { squamous cell } \\
\text { carcinoma of the } \\
\text { oral cavity) }\end{array}$ & NA & NA & $\begin{array}{c}0 \% \text { (without TA) } \\
4 \% \text { (with TA) } \\
7 \% \text { (with TA + CMD) }\end{array}$ & Ndong2015 \\
\hline $\begin{array}{c}\text { SPION + } \\
\text { human serum albumin } \\
\text { (with TA) }\end{array}$ & iv & $\begin{array}{l}0.12 \mathrm{mg} \\
\text { (mice) }\end{array}$ & $\begin{array}{l}\text { HAS may } \\
\text { interact with gp } 60 \text { and } \\
\text { SPARC and yield improved } \\
\text { extravasation and tumor } \\
\text { accumulation }\end{array}$ & $4 \mathrm{~T} 1$ breast tumor & $\begin{array}{c}500 \mathrm{~mm}^{3} \\
0.6 \mathrm{~g}\end{array}$ & $2 \%$ (with TA) & $1.2 \%$ (with TA) & Quan2011 \\
\hline $\begin{array}{l}\text { SPION + RGD } \\
\text { (with TA) }\end{array}$ & iv & $\begin{array}{l}0.2 \mathrm{mg} \\
\text { (mice) }\end{array}$ & $\begin{array}{l}\text { Targets } \alpha_{v} \beta_{3} \text { integrin- } \\
\text { expressing U87MG cells }\end{array}$ & $\begin{array}{l}\text { Glioblastoma } \\
\text { U87-MG }\end{array}$ & $\begin{array}{c}180 \mathrm{~mm}^{3} \\
0.2 \mathrm{~g}\end{array}$ & 2.6-5.4\% (with TA) & $0.6-1.2 \%$ (with TA) & Yang2011 \\
\hline $\begin{array}{c}\text { SPION + PEG (without TA) } \\
\text { SPION + PEG + } \\
\text { Trastuzumab (with TA) }\end{array}$ & iv & $\begin{array}{l}0.5 \mathrm{mg} \\
\text { (mice) }\end{array}$ & $\begin{array}{l}\text { Trastuzufab antibody } \\
\text { binds to HER2 expressed } \\
\text { on tumor cells }\end{array}$ & $\begin{array}{l}\text { SkBr3 breast } \\
\text { cancer cells }\end{array}$ & $\begin{array}{c}65 \mathrm{~mm}^{3} \\
0.1 \mathrm{~g}\end{array}$ & $\begin{array}{l}0 \% \text { (without TA) } \\
8.8 \% \text { (with TA) }\end{array}$ & $\begin{array}{c}0 \% \text { (without TA) } \\
0.9 \% \text { (with TA) }\end{array}$ & Zolata2015 \\
\hline
\end{tabular}


Magnetic targeting of tumors with different types of iron oxyde nanoparticle

\begin{tabular}{|c|c|c|c|c|c|c|c|c|}
\hline IONP type & $\begin{array}{c}\text { Admin. } \\
\text { Route }\end{array}$ & $\begin{array}{l}\text { Quantity } \\
\text { Admin. } \\
\text { (animal) }\end{array}$ & $\begin{array}{l}\text { Strength of } \\
\text { magnetic field } \\
\text { (with MT) }\end{array}$ & $\begin{array}{c}\text { Type of } \\
\text { targeted tumor }\end{array}$ & \begin{tabular}{|c|} 
Tumor size \\
Tumor weight
\end{tabular} & $\begin{array}{c}\text { Percentage of IONP in } \\
\text { tumor } \\
\text { (\% ID/g tissue) }\end{array}$ & $\begin{array}{c}\text { Percentage of IONP in } \\
\text { tumor } \\
\text { (\% ID) }\end{array}$ & Ref. \\
\hline $\begin{array}{l}\text { SPION encapsulated } \\
\text { in nanocapsule }\end{array}$ & iv & $\begin{array}{c}2 \mathrm{mg} \\
\text { (mice) }\end{array}$ & $0.43 \mathrm{~T}$ & $\begin{array}{l}\text { CT-26 colon } \\
\text { tumor }\end{array}$ & $\begin{array}{c}100 \mathrm{~mm}^{3} \\
0.2 \mathrm{~g}\end{array}$ & $\begin{array}{c}6 \% \text { (with MT) } \\
2 \% \text { (without MT) }\end{array}$ & $\begin{array}{c}0.6 \% \text { (with MT) } \\
0.2 \% \text { (without MT) }\end{array}$ & Al-Jamal2016 \\
\hline $\begin{array}{l}\text { G100 starch coated IONP } \\
\text { (Chemicell) }\end{array}$ & iv & $\begin{array}{l}1.7 \mathrm{mg} \\
\text { (rats) }\end{array}$ & $0.4 \mathrm{~T}$ & 9L glioma & $\begin{array}{l}50-70 \mathrm{~mm}^{3} \\
\quad 0.1 \mathrm{~g}\end{array}$ & $\begin{array}{c}5.10^{-2} \% \text { (with MT) } \\
5.10^{-3} \% \text { (without MT) }\end{array}$ & $\begin{array}{c}5.10^{-3} \% \text { (with MT) } \\
5.10^{-4} \% \text { (without MT) }\end{array}$ & Chertok2007 \\
\hline $\begin{array}{c}\text { G-PEI starch coated IONP } \\
\text { (zeta potential }=37 \mathrm{mV} \text {, Chemicell) }\end{array}$ & ia & $\begin{array}{l}1.7 \mathrm{mg} \\
\text { (rats) }\end{array}$ & $0.35 \mathrm{~T}$ & 9L glioma & $\begin{array}{l}70-90 \mathrm{~mm}^{3} \\
0.2 \mathrm{~g}\end{array}$ & $0.34 \%$ (with MT) & $0.068 \%$ (with MT) & Chertok2010 \\
\hline $\begin{array}{c}\text { G-100 starch coated IONP } \\
\text { (Zeta potential }=-12 \mathrm{mV} \text {, Chemicell) }\end{array}$ & ia & $\begin{array}{l}1.7 \mathrm{mg} \\
\text { (rats) }\end{array}$ & $0.35 \mathrm{~T}$ & 9L glioma & $\begin{array}{l}70-90 \mathrm{~mm}^{3} \\
0.2 \mathrm{~g}\end{array}$ & $0.08 \%$ (with MT) & $0.16 \%$ (with MT) & Chertok2010 \\
\hline $\begin{array}{l}\text { SPION (6-10 nm) } \\
\text { (Taiwan advanced Nanotech) }\end{array}$ & iv & $\begin{array}{l}0.3 \mathrm{mg} \\
\text { (rats) }\end{array}$ & $0.5 \mathrm{~T}$ & C6 glioma & $\begin{array}{c}20 \mathrm{~mm}^{3} \\
0.1 \mathrm{~g}\end{array}$ & $\begin{array}{c}5 \% \text { (with MT + FUS) } \\
2 \% \text { (with MT) } \\
1 \% \text { (without MT) }\end{array}$ & $\begin{array}{c}0.5 \% \text { (with } \mathrm{MT}+\text { FUS) } \\
0.2 \% \text { (with } \mathrm{MT} \text { ) } \\
0.1 \% \text { (without MT) }\end{array}$ & Fan2013 \\
\hline $\begin{array}{c}\text { SPION with } \\
\text { amino groups }(36 \mathrm{~nm})\end{array}$ & iv & $\begin{array}{l}4 \mathrm{mg} \\
\text { (rats) }\end{array}$ & $0.5 \mathrm{~T}$ & C6 glioma & $\begin{array}{c}23 \mathrm{~mm}^{3} \\
0.1 \mathrm{~g}\end{array}$ & $\begin{array}{l}0.5-0.8 \% \text { (with MT) } \\
0.1 \% \text { (without MT) }\end{array}$ & $\begin{array}{c}0.05-0.08 \% \text { (with MT) } \\
0.01 \% \text { (without MT) }\end{array}$ & Fan2016 \\
\hline SPION embedded nanobubbles & iv & $\begin{array}{l}3 \mathrm{mg} \\
\text { (rats) }\end{array}$ & $1.2 \mathrm{~T}$ & Glioma tumor & $\begin{array}{c}100 \mathrm{~mm}^{3} \\
0.2 \mathrm{~g}\end{array}$ & $\begin{array}{c}\text { 7\% (with MT) } \\
\text { 3\% (without MT) }\end{array}$ & $\begin{array}{c}\text { 1.4\% (with MT) } \\
0.6 \% \text { (without MT) }\end{array}$ & Huang2013 \\
\hline SPION (ZnMnFeO) & iv & $\begin{array}{l}0.8 \mathrm{mg} \\
\text { (mice) }\end{array}$ & $\begin{array}{l}\text { Neodinium } \\
\text { magnet }\end{array}$ & 4T1 tumor & $\begin{array}{c}150 \mathrm{~mm}^{3} \\
0.2 \mathrm{~g}\end{array}$ & $\begin{array}{c}\text { 12\% (with MT) } \\
5 \% \text { (without MT) }\end{array}$ & $\begin{array}{l}\text { 2.4\% (with MT) } \\
1 \% \text { (without MT) }\end{array}$ & $\mathrm{Ni} 2018$ \\
\hline $\mathrm{MoS}_{2} \mathrm{Fe}_{3} \mathrm{O}_{4}$ & iv & $\begin{array}{l}0.4 \mathrm{mg} \\
\text { (mice) }\end{array}$ & N.A. & $\begin{array}{l}\text { PANC-1 } \\
\text { (pancreatic } \\
\text { tumor) }\end{array}$ & $\begin{array}{c}100 \mathrm{~mm}^{3} \\
0.2 \mathrm{~g}\end{array}$ & $4 \%$ (with MT) & $0.8 \%$ (with MT) & Yu2015 \\
\hline $\begin{array}{l}\text { Starch coated D-MNP (Chemicell) } \\
\text { conjugated with PEG and } \beta \text {-glucosidase }\end{array}$ & iv & $\begin{array}{l}0.24 \mathrm{mg} \\
\text { (mice) }\end{array}$ & $0.32 \mathrm{~T}$ & 9L glioma & $\begin{array}{l}300-400 \mathrm{~mm}^{3} \\
0.4 \mathrm{~g}\end{array}$ & $\begin{array}{l}6.5 \% \text { (with } \mathrm{MT} \text { ) } \\
1 \% \text { (without } \mathrm{MT} \text { ) }\end{array}$ & $\begin{array}{c}2.6 \% \text { (with MT) } \\
0.4 \% \text { (without MT) }\end{array}$ & Zhou2014 \\
\hline $\begin{array}{l}\text { Starch coated D-MNP (Chemicell) } \\
\text { conjugated with } \beta \text {-glucosidase }\end{array}$ & iv & $\begin{array}{l}0.24 \mathrm{mg} \\
\text { (mice) }\end{array}$ & $0.32 \mathrm{~T}$ & 9L glioma & $\begin{array}{l}300-400 \mathrm{~mm}^{3} \\
0.4 \mathrm{~g}\end{array}$ & $\begin{array}{c}3 \% \text { (with MT) } \\
0.5 \% \text { (without } \mathrm{MT} \text { ) }\end{array}$ & $\begin{array}{c}1.2 \% \text { (with } \mathrm{MT} \text { ) } \\
0.2 \% \text { (without } \mathrm{MT} \text { ) }\end{array}$ & Zhou2014 \\
\hline Starch coated D-MNP (Chemicell) & iv & $\begin{array}{l}0.24 \mathrm{mg} \\
\text { (mice) }\end{array}$ & $0.32 \mathrm{~T}$ & 9L glioma & $\begin{array}{l}300-400 \mathrm{~mm}^{3} \\
0.4 \mathrm{~g}\end{array}$ & $\begin{array}{c}1 \% \text { (with MT) } \\
0.1 \% \text { (without } \mathrm{MT} \text { ) }\end{array}$ & $\begin{array}{c}0.4 \% \text { (with MT) } \\
0.04 \% \text { (without MT) }\end{array}$ & Zhou2014 \\
\hline
\end{tabular}

Table 5 